\title{
A review of the Cenozoic fossil record of the genus Zamia L. (Zamiaceae, Cycadales) with recognition of a new species from the late Eocene of Panama - evolution and biogeographic inferences
}

\author{
Boglárka Erdei, Michael Calonje, Austin Hendy \& Nicolas Espinosa
}

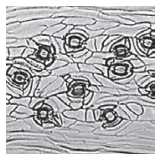

\begin{abstract}
Modern Zamia L. is the second largest genus among cycads, however reliably identified fossil occurrences of the genus have so far been missing. Previously, fossil "Zamia" species were established in large numbers on the basis of macromorphological similarity of foliage fragments to living Zamia species. However, a reinvestigation of specimens assigned formerly to Zamia and the relevant literature provided no clear-cut evidence for their assignment to this genus. We investigated a newly recovered fossil specimen from marine sediments of the Gatuncillo Formation, near Buena Vista, Colon Province, Central Panama. It represents the first unequivocal fossil record of the genus confirmed by epidermal as well as macromorphological characters and it is described as Zamia nelliae Erdei \& Calonje sp. nov. Foraminiferal and nannoplankton biostratigraphy of the locality indicates a late Eocene to earliest Oligocene age. Morphometric comparison of epidermal features of Z. nelliae with those of modern Zamia species suggests similarity with those of the Caribbean Zamia clade. The fossil record of Zamia from Panama implies that the genus appeared by the end of the Eocene or earliest Oligocene in the Central American-Caribbean region, however, the origin of the genus is still unresolved. The record of Z. nelliae may challenge former concepts on the evolution of Zamia and raises an "intermediate" hypothesis on its origin in the Central American-Caribbean region and its subsequent dispersal south- and northwards. $•$ Keywords: cycad, Zamia, cuticle, morphometry, Paleogene, Panama.
\end{abstract}

Erdei, B., Calonje, M., Hendy, A. \& Espinosa, N. 2018. A review of the Cenozoic fossil record of the genus Zamia L. (Zamiaceae, Cycadales) with recognition of a new species from the late Eocene of Panama - evolution and biogeographic inferences. Bulletin of Geosciences 93(2), 185-204 (6 figures, 2 tables). Czech Geological Survey, Prague. ISSN 1214-1119. Manuscript received April 25, 2017; accepted in revised form October 27, 2017; published online June 18, 2018; issued June 30, 2018.

Boglárka Erdei, Hungarian Natural History Museum, Botanical Department, Budapest, 1087 Könyves K. krt. 40, Hungary; erdei.boglarka@nhmus.hu • Michael Calonje, Montgomery Botanical Center, 11901 Old Cutler Road, Miami, Florida, 33156, USA \& Department of Biological Sciences, Florida International University, Miami, FL 33199, USA; michaelc@montgomerybotanical.org • Austin Hendy, Invertebrate Paleontology, Natural History Museum of Los Angeles County, 900 Exposition Blvd, Los Angeles, CA 90007, USA \& Center for Tropical Paleontology and Archaeology, Smithsonian Tropical Research Institute, Balboa Ancon, Panama, Republic of Panama; ahendy@nhm.org・ Nicolas Espinosa, Department of Biological Sciences, Florida International University, Miami, FL 33199, USA

Cycads today comprise 349 accepted species in ten genera (Calonje et al. 2017). The number of cycad species described during the last decade increased significantly as a result of intense fieldwork by botanists. Recent results of phylogenetic studies of cycads suggested a relatively recent, late Miocene radiation of cycad species along with the Paleogene appearance of most of the major clades (genera excluding Cycas L. and Dioon Lindl.) and have challenged the theory of "living fossil cycads" (Nagalingum et al. 2011, Salas-Leiva et al. 2013, Condamine et al. 2015). These studies estimated the divergence of Microcycas-Zamia to the late Eocene--early Oligocene.
Zamia, with 77 currently accepted species (Calonje et al. 2017) is the second largest genus of cycads, and is the most morphologically and ecologically diverse genus in the extant Cycadales (Norstog \& Nichols 1997). Furthermore it is the most speciose and broadly distributed cycad genus in the New World. The centre of diversity for the genus appears to be northern South America and Central America, as the highest species diversity occurs in Colombia (21 species) and Panama (17 species). Zamia species inhabit a great variety of habitats including areas near mangrove swamps (Zamia roezlii Linden), dry desert-like areas (Zamia encephalartoides D.W. Stev.), coastal sand dunes (Zamia lucayana Britton), 
and even occur as obligate cliff dwellers (Z. meermanii Calonje) and obligate epiphytes (Z. pseudoparasitica J. Yates). Microcycas (Miq.) A. DC., a monotypic genus, is well supported as the sister genus to Zamia (including Chigua D.W. Stev.) in both morphological (e.g. Crane 1988, Stevenson 1990) and molecular-based (e.g. Hill 2003, Chaw et al. 2005) phylogenetic studies. Caputo et al. (2004) published a phylogeny of Zamia combining morphological characters and sequence data from the internal transcribed spacer 2 (ITS2). They found phylogenetic patterns reflecting geographical distribution, with separate clades resolved for mainly Caribbean, Mexican, Central American, and South American species.

Despite the relative importance of modern Zamia among cycads, well documented fossil occurrences of the genus have so far been missing. This situation contrasts with some other extant cycad genera that have been more convincingly recognized in the fossil record, e.g. Bowenia Hook ex Hook f. (Hill 1978), Ceratozamia Brongn. (Kvaček, Z. 2002, 2004, 2014), Cycas (Yokoyama 1911, Su et al. 2014), Lepidozamia Regel (Hill 1980), and Macrozamia Miq. (Carpenter 1991). A large number of purported fossil "Zamia" species have been established on the basis of macromorphological similarity of leaflets or leaflet fragments to leaflets of living Zamia species. Putative fossil records of Zamia were mentioned from both America and Europe, with much higher frequency in North America. Most of these reports were based on solitary leaflets which is congruent with the articulate character of the leaflets in the genus (and in two other closely related genera, Ceratozamia and Microcycas).

The macromorphological similarity of cycad leaves hinders the systematic treatment, of fossils because these cannot be identified securely based only on gross morphology. However, the assignment of the majority of cycad leaf remains to extant genera can be corroborated with the analyses of epidermal traits combined with gross morphological characters. The shape and arrangement of epidermal cells on the adaxial and abaxial epidermis, the occurrence or absence of cells or group of cells having differently thickened cell walls, and the shape and arrangement of stomata all give clues to differentiate extant zamiaceous cycad genera (see also Greguss 1968) In most Zamia species, epidermal traits, i.e. elongate, almost linear, epidermal cells with convex, non-angular anticlinals on both the upper and lower epidermis being devoid of cell groups with heavily thickened cell walls, the more or less parallel oriented, isodiametric stomata arranged in bands, complement macromorphological traits. Previous reports of fossil Zamia were exclusively based on macromorphological traits, lacking confirmation from epidermal characters. The first author re-examined many specimens that were formerly described as Zamia by Berry (1916a, b, 1917, 1930), Brown (1962), and Hollick (1928) during the first half of the $20^{\text {th }}$ century and were available from museum collections whereas some other specimens have already been revisited and excluded from the genus, and partly transferred to the extinct Dioonopsis (e.g. Erdei et al. 2012, Wilf et al. 2014).

Herein, we review the published fossil records of Zamia based on reinvestigation of physical specimens and the relevant literature and describe the first fossil evidence of Zamia from Paleogene sediments of Panama. In order to assess the morphological relation of the fossil species, $Z$. nelliae Erdei et Calonje to modern Zamia species we applied morphometric analyses of the epidermal traits of the fossil and numerous modern Zamia species representing all major Zamia clades (Calonje, unpublished phylogenetic research).

\section{Geological setting}

The fossil described herein as Zamia nelliae was collected by A. Hendy from sediments referred to the Gatuncillo Formation exposed in Colon Province, Central Panama (Fig. 1). The Gatuncillo Formation crops out in rolling lowlands to the east of the Panama Canal, overlying Cretaceous basement, and in turn being overlain by either Oligocene or Miocene sediments (Woodring 1973). Historically, workers have considered the Gatuncillo to be middle to upper Eocene on the basis of planktonic foraminifera (Coryell \& Embich 1937), large benthic foraminifera (Cole 1949, 1952), and mollusks, corals, and echinoderms (see Woodring 1973 for discussion). Ramírez et al. (2016) using U-Pb geochronology found ages for the Gatuncillo Formation at two sites no younger than 36 and $41 \mathrm{Ma}$, respectively. Strontium isotope analyses $\left({ }^{87} \mathrm{Sr} /{ }^{86} \mathrm{Sr}\right.$ ) by Tripathi \& Zachos (2002) also supported a Priabonian (37.8-33.9 Ma) age, although most samples were likely impacted by diagenetic alteration.

The locality (STRI loc. 290268) is $1.5 \mathrm{~km} \mathrm{~S}$ of Buena Vista, on the NE side of the Madden-Colón road (Transisthmica), and $46 \mathrm{~km} \mathrm{SE}$ of Colón $\left(9^{\circ} 16^{\prime} 4.80^{\prime \prime} \mathrm{N}\right.$, $\left.79^{\circ} 41^{\prime} 15.83^{\prime \prime} \mathrm{W}\right)$. This section has now been destroyed through continued quarrying of rock for construction fill, but previously exposed some $20 \mathrm{~m}$ of mudstone and carbonaceous sandstone. Compression fossils of various plants were collected from a steeply dipping carbonaceous sandstone bed, along with infrequent molds of bivalves and gastropods of nearshore affinity. These overlay a thick succession of mudstone, with sparse molluscs, including nuculanid and corbulid bivalves, turrid gastropods, Dentalium (Scaphopoda), and Aturia (Cephalopoda). This fauna, together with the fine and massive siliciclastic sediments indicate an offshore (mid-shelf to outer shelf) setting for the overlying mudstone facies. Foraminifera in this facies are abundant, and include Hantkenina alabamensis, Turbototalia cerrozazulensis, and Chiloguemblina cubensis. Characteristic nannoplankton includes Cribrocentrum reticulatum, Reticulofenestra umbilicus, Helicosphaera euphratis, Pontosphaera multipora. Nannoplankton and 


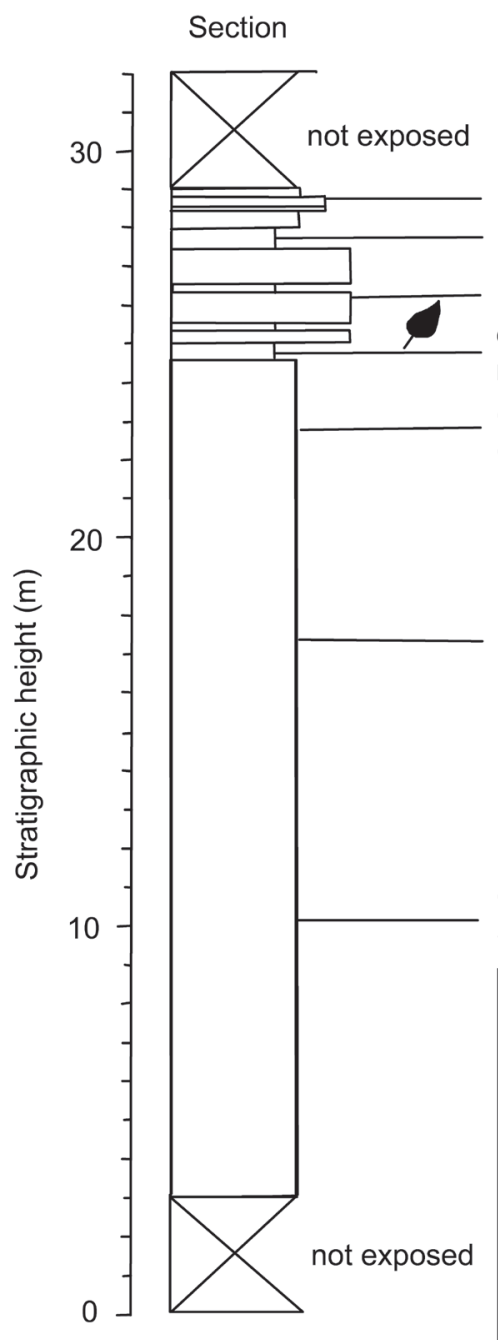

Lithology

Figure 1. Map showing the locality of $Z$. nelliae and geological section of the Gatuncillo Formation. The leaf symbol indicates layers yielding plant fossils including $Z$. nelliae.

light grey mudstone sparsely fossiliferous

dark grey mudstone sparsely fossiliferous

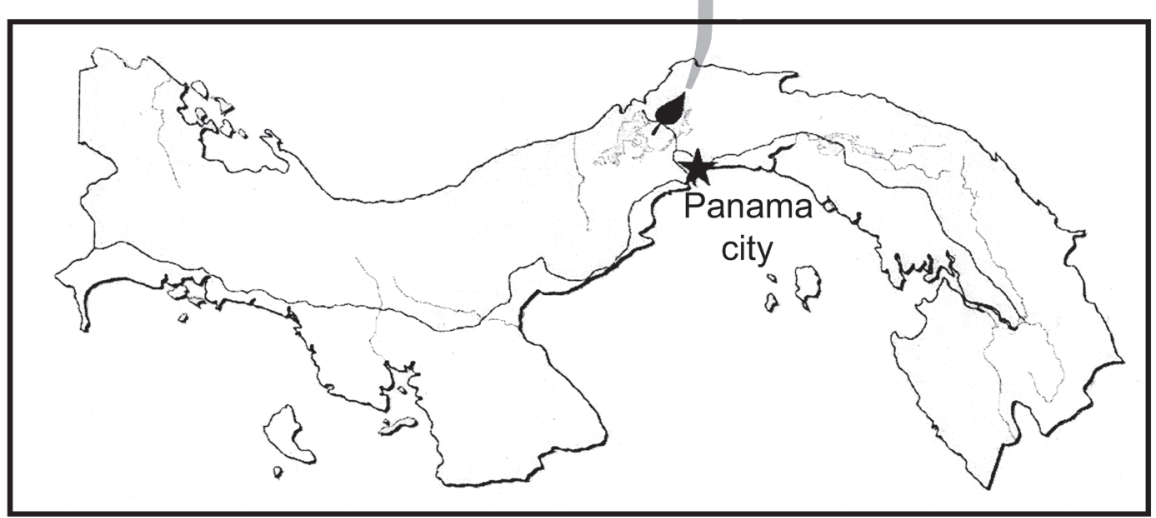

foraminiferal biostratigraphy place this underlying succession in to zones P14-P17 (Bartonian-Priabonian) and NP18-NP21 (Priabonian-Rupelian), respectively (Hendy \& Machado unpublished data). Since there is no major unconformity at the base of the Zamia-bearing strata, it is assumed that the Zamia-bearing horizon is no older than the Priabonian, but more likely to be latest Priabonian-earliest Rupelian in age.

\section{Material and methods}

\section{Material}

The fossil described herein as Zamia nelliae is deposited in the Paleobotany collection of the Florida Museum of Natural History (UF 19531-70503 /STRI 36903/). Repositories for other material from the section which yielded the fossil
Zamia include the Invertebrate Paleontology collection of the Natural History Museum of Los Angeles County for macrofossils (LACMIP loc. 41768), and the Smithsonian Tropical Research Institute Center for Tropical Paleontology and Archaeology for microfossils (STRI loc. 290268).

Specimens formerly assigned to Zamia and re-examined here include those of Z. australis Berry (Berry 1928, Argentina; USNM 37857/holotype), Z. mississippiensis Berry (Berry 1916a, 1917, Wilcox flora; USNM35473, 35501, 35502/types), Z. tennesseeana Berry (Berry 1930, Tennessee; USNM39727/holotype), Z. (?) wilcoxensis Berry (Berry 1916b, Wilcox flora; USNM35474/holotype), Z. collazoensis Hollick (Hollick 1928, Puerto Rico; YPM25440, 27131/holotype/, 27141, 27144), Z. noblei Hollick (Hollick 1928, Puerto Rico; YPM25445ab/paratype/, 27140, 27152, 27169/type/, 27170, 27498/?type/), Podozamites latipennis Heer /Z. coloradensis (Knowlton) Brown (Brown 
1962, Wyoming; USNM40155/?lectotype), Z. wyomingensis Brown (Brown 1962, Wyoming; USNM167487/holotype), Zamia washingtoniana Ward (Ward 1895, Potomac, Cretaceous; USNM31768a,b, 31769a,b/types).

The following extant species of Ceratozamia (24 species) and Microcycas (1 species) were studied for comparison: Ceratozamia alvarezii Pérez-Farr., Vovides \& Iglesias (MBC 20010258A, FTG D. Little \& D.W. Stevenson 1102), C. becerrae Pérez-Farr., Vovides \& Schutzman (MBC 20010249), C. brevifrons Miq. (MBC 98618E), C. chimalapensis Pérez-Farr. \& Vovides (MBC 20020073F), C. decumbens Vovides, Avendańo, Pérez-Farr. \& Gonz.Astorga (MBC 20010924A), C. euryphyllidia Vázq.Torres, Sabato \& D.W. Stev. (FTBG89334A), C. fuscoviridis Moore ex R. Osborne, D.W. Stev. \& Vovides (MBC20010167A), C. hildae G.P. Landry \& M.C. Wilson (MBC 88339), C. kuesteriana Regel (MBC 931202A), C. latifolia Miq. (MBC 931178A), C. matudae [Stevenson et al., 681 (FTG)], C. mexicana Brongn. (FTBG 67881), C. microstrobila Vovides \& J.D. Rees (MBC 931220A), C. miqueliana H. Wendl. (MBC 20010235A), C. mirandae Vovides, Pérez-Farr. \& Iglesias (MBC 20020252), C. mixeorum Chemnick, T.J. Greg. \& Salas-Mor. [J. Chemnick \& T.J. Gregory 51 (FTG)], C. morettii Vázq. Torres \& Vovides (MBC 20010161A), C. norstogii D.W. Stev. (MBC 93944G), C. robusta Miq. (MBC 20120345A), C. sabatoi Vovides, Vázq.Torres, Schutzman \& Iglesias (MBC 20010176A), C. vovidesii Pérez-Farr. \& Iglesias, (MBC 20020826F), C. whitelockiana Chemnick \& T.J. Greg. [J. Chemnick \& T.J. Gregory 51 (FTG)], C. zaragozae Medellín (MBC 20010182A), C. zoquorum Pérez-Farr., Vovides \& Iglesias, (MBC 20011365A), Microcycas calocoma (Miq.) A. DC. (MBC RM384A).

Zamia species adopted for comparison and morphometric measurements are listed in Table 1. (39 species in total, 32 species in morphometry plus samples of selected Caribbean clade species from various localities). Additional information on the macro- and micromorphology of Zamia leaves was obtained from Greguss (1968) and Schutzman (1998). Greguss (1968) provided a key to the genera of cycads based on epidermal features, however its usefulness is partly limited since having at that time only a fragment (18 Zamia species) of the currently recognized cycad species (349 cycad species, 77 Zamia species, Calonje et al. 2017).

Studies of epidermal details in additional cycad genera include Bowenia serrulata (W.Bull) Chamb. (MBC 20040865R), Cycas revoluta Thunb. (Herbarium of the Szafer Institute, Krakow), Dioon edule Lindl. (fresh material, Botanical Garden of the University of Naples), D. mejiae Standl. \& L.O. Williams (fresh material, Toowong Botanical Gardens, Brisbane), D. purpusii Rose (fresh material, Toowong Botanical Gardens, Brisbane), D. rzedowskii De Luca, A. Moretti, Sabato \& Vázq. Torres (fresh material, Botanical Garden of the University of Naples), D. spinulosum Dyer ex Eichler (fresh material, Botanical Garden of the
University of Naples), Encephalartos eugene-maraisii I. Verd. (fresh material, Botanical Garden of the University of Naples), E. ferox G. Bertol (MBC 78357F), E. gratus Prain (MBC 64561F), E. hildebrandtii A. Braun \& C.D. Bouché (MBC 651375A), E. inopinus R.A. Dyer (fresh material, Botanical Garden of the University of Naples), E. manikensis (Gilliland) Gilliland (MBC 971643A), E. sclavoi A. Moretti, D.W. Stev. \& De Luca (fresh material, Toowong Botanical Gardens, Brisbane), Lepidozamia peroffskyana Regel (MBC 651328A), Macrozamia communis L.A.S. Johnson (MBC 60385A), M. moorei F. Muell. (MBC 59302B), M. lucida L.A.S. Johnson (MBC 59691C), Stangeria eriopus (Kunze) Baill. (MBC 651325K). Additional information on epidermal details of Dioon was obtained from Barone Lumaga et al. (2015).

Abbreviations. - FTBG - Fairchild Tropical Botanical Garden, Florida, USA; FTG - Herbarium of the Fairchild Tropical Botanical Garden, Florida, USA; MBC Montgomery Botanical Center, Florida, USA; Nong Nooch Nong Nooch Tropical Botanical Garden, Thailand; Selby - Marie Selby Botanical Gardens, Florida, USA; USNM Smithsonian Institution, Washington DC, USA; YPM - Yale Peabody Museum of Natural History, Connecticut, USA.

\section{Methods}

Epidermal characters of fossil specimens were studied using transmitted light, epifluorescence, and scanning electron microscopy. For these purposes cuticle fragments were removed from the specimen and cleaned in hydrofluoric acid. In addition, epifluorescence was applied on cuticles that were intact on the shale. For studies with transmitted light and electron microscopy, cuticle samples were macerated following the conventional method (Jones \& Rowe 1999) and were stained with safranin. Cuticles were studied using Zeiss Axiophot microscope equipped with an Axiocam digital camera. Scanning electron microscopy was performed on a Hitachi S-4000 FE-SEM. Microscopic slides of fossil material are stored in the Florida Museum of Natural History (Gainesville).

Leaf material of extant cycads for comparison was treated with $20 \% \mathrm{CrO}_{3}$ for $48-72 \mathrm{~h}$ or more as required, at room temperature and stained with safranin when desired. For consistency, samples were taken from the centre of leaflet lamina and the leaflets were collected from the middle part of each sampled leaf.

Microscopic slides of extant leaf material are stored in the Hungarian Natural History Museum, Botanical Department (Budapest, Hungary).

Morphometric analyses of epidermal characters were carried out for 35 extant Zamia samples (including $Z$. aff. portoricensis Urb. and samples of $Z$. pygmaea Sims 
Table 1. List of Zamia species used for comparison. Bold face indicates species included in morphometric analysis. Abbreviations of clades: C - Caribbean; F - Fischeri; I - Isthmus; M - Megamexico; S - South America.

\begin{tabular}{|c|c|c|c|}
\hline Taxon & Provenance & Clade & Accession / Voucher \\
\hline Z. erosa O.F. Cook \& G.N. Collins & Puerto Rico & $\mathrm{C}$ & MBC $20030275^{*} \mathrm{D}$ \\
\hline Z. integrifolia L.f. & Florida (USA) & $\mathrm{C}$ & MBC $20050880 * \mathrm{~B}$ \\
\hline Z. lucayana Britton & Long Island, Bahamas & $\mathrm{C}$ & MBC 20090823 \\
\hline Z. portoricensis Urb. & Puerto Rico & $\mathrm{C}$ & MBC 20030469A \\
\hline Z. pumila L. (Puerto Rico) & Puerto Rico & $\mathrm{C}$ & MBC 20080285B \\
\hline Z. pygmaea Sims & Cuba & $\mathrm{C}$ & Calonje et al. CU13-003(FTG) \\
\hline Z. pygmaea (formerly Z. silicea) & Cuba & $\mathrm{C}$ & Calonje et al. CU13-007(FTG) \\
\hline Z. aff. portoricensis & Jamaica & $\mathrm{C}$ & MBC 20030357 \\
\hline Z. angustifolia Jacq. (Cuba) & Cuba & $\mathrm{C}$ & MBC 20110318 \\
\hline Z. angustifolia (Bahamas) & Eleuthera, Bahamas & $\mathrm{C}$ & FTBG $9548 *$ A \\
\hline Z. stricta Miq. & Cuba & & MBC 20110318 \\
\hline Z. fischeri Miq. & Tamaulipas, Mexico & $\mathrm{F}$ & MBC $20010205^{*} \mathrm{~A}$ \\
\hline Z. inermis Vovides, J.D. Rees \& Vázq. Torres & Mexico & $\mathrm{F}$ & MBC $92143 * D$ \\
\hline Z. nelliae (fossil) & Panama & & STRI 36903 \\
\hline Z. acuminata Oerst. ex Dyer & Costa Rica & I & MBC 20041004 \\
\hline Z. dressleri D.W. Stev. & Panama & I & Selby1996-0009 \\
\hline Z. elegantissima Schutzman, Vovides \& R.S. Adams & Panama & I & $\mathrm{MBC} 2000775^{*} \mathrm{G}$ \\
\hline Z. imperialis A.S. Taylor, J.L. Haynes \& Holzman & Panama & I & MBC $2000265^{*} \mathrm{~A}$ \\
\hline Z. lindleyii Warsz. ex A. Dietr. & Panama & I & MBC $20010802 * A$ \\
\hline Z. nana A. Lindstr., Calonje, D.W. Stev. \& A.S.Taylor & Panama & I & MBC $20020234 * B$ \\
\hline Z. nesophila A.S. Taylor, J.L. Haynes \& Holzman & Panama & I & MBC $20010123 * A$ \\
\hline Z. obliqua A. Braun & Colombia & I & FTG 89162 \\
\hline Z. pseudoparasitica J. Yates & Panama & I & MBC $2000319 * A$ \\
\hline Z. cremnophila Vovides, Schutzman \& Dehgan & Mexico & M & FTBG 87339 \\
\hline Z. decumbens Calonje, Meerman, M.P. Griff. \& Hoese & Belize & M & MBC 20080715 \\
\hline Z. furfuracea L.f. & Mexico & M & MBC $20010214 * H$ \\
\hline Z. lacandona Schutzman \& Vovides & Mexico & M & MBC $93939 * A$ \\
\hline Z. loddigesii Miq. & Mexico & M & MBC $99801 * A$ \\
\hline Z. onan-reyesii C. Nelson \& Sandoval & Honduras & M & MBC 20030877Q \\
\hline Z. purpurea Vovides, J.D. Rees \& Vázq. Torres & Mexico & M & FTBG $93928 * N$ \\
\hline Z. soconuscensis Schutzman, Vovides \& Dehgan & Mexico & M & MBC $20030717 * A$ \\
\hline Z. variegata Warsz. & Guatemala & M & FTBG $73196 *$ B \\
\hline Z. amplifolia W. Bull ex Mast. & Colombia & $\mathrm{S}$ & FTG 91596/Bogler 1223 \\
\hline Z. disodon D.W. Stev. \& Sabato & Colombia & $\mathrm{S}$ & cult. Nong Nooch \\
\hline Z. encephalartoides D.W. Stev. & Colombia & $\mathrm{S}$ & MBC $94910 * A$ \\
\hline Z. ipetiensis D.W. Stev. & Panama & $\mathrm{S}$ & MBC $2000279 * A$ \\
\hline Z. lindenii Regel ex André & Ecuador & S & MBC $20001000 * \mathrm{~F}$ \\
\hline Z. manicata Linden ex Regel & Panama & $\mathrm{S}$ & FTBG $84272 * V$ \\
\hline Z. restrepoi (D.W. Stev.) A. Lindstr. & Colombia & $\mathrm{S}$ & MBC 20100026A \\
\hline Z. pyrophylla Calonje, D.W. Stev. \& A. Lindstr. & Colombia & $\mathrm{S}$ & MBC $20100027 * A$ \\
\hline Z. roezlii Linden & Colombia & $\mathrm{S}$ & MBC $94635 * \mathrm{~B}$ \\
\hline Z. urep B. Walln. & Peru & $\mathrm{S}$ & cult. Nong Nooch \\
\hline Z. wallisii A. Braun & Colombia & $\mathrm{S}$ & MBC $20010301 * A$ \\
\hline
\end{tabular}


and $Z$. angustifolia Jacq. from various localities) and the fossil Zamia by taking various measurements using ImageJ v. 1.47 (Rasband WS. ImageJ, U.S. National Institutes of Health, Bethesda, Maryland, USA; https://imagej.nih.gov/ ij/, 1997-2012) on spatially calibrated slide photographs. Modern species were selected to include all the major Zamia clades (Calonje unpublished phylogenetic data; Tab. 1).

For abaxial surfaces, the following characters were measured: stomatal index, mean stomatal pore length, standard deviation of stomatal pore angle, mean interstomatal band width (the width of the area between two stomatal bands), mean stomatal band width, mean stomatal band to interstomatal band width ratio. For adaxial surfaces, the following characters were measured: mean adaxial cell area, standard deviation of adaxial cell angle, mean adaxial cell length, mean adaxial cell width, mean adaxial cell circularity $=$ $4 \pi$ (Area/Perimeter $\left.{ }^{\wedge} 2\right)$, mean adaxial cell aspect ratio, mean adaxial cell roundness $=4 \times[$ Area $] / \pi \times[\text { Major axis }]^{2}$, and mean adaxial cell solidity $=[$ Area $] /[$ Convex area $]$.

Stomatal index was estimated by counting stomata and epidermal cells occurring in an area of approximately $0.25 \mathrm{~mm}^{2}$ within stomatal bands and by using the formula [number of stomata/(number of stomata + number of epidermal cells) $] \times 100$ and measurements were made by averaging 3 measurements taken in different regions of the slide preparations. A recent study by Haworth et al. (2011) showed that selected cycad species (six cycad genera including Zamia, each represented by one species) showed no significant stomatal density or index response to changes in ambient $\mathrm{CO}_{2}$ or $\mathrm{O}_{2}$. Thus, it may be inferred that varying atmospheric $\mathrm{CO}_{2}$ level does not influence stomatal density/ index of the fossil Zamia species.

Stomatal angle (orientation of stomata) was calculated in Image $\mathrm{J}$ by drawing the long axis of the stomatal lit and calculating the angle of this line to the stomatal band. Stomatal and interstomatal bands were measured by averaging 5 measurements taken in different regions of the slide preparations. Adaxial cell measurements were taken by selecting between 40 and 67 individual cells along a transect for every species, and thresholding them for particle analysis in ImageJ. Individual cell measurements were averaged except for angular measurements in which the standard deviation was recorded to measure the variation in the angles. All measurements were used in a Principal Coordinate Analysis executed in SPSS (IBM Corp. Released 2012. IBM SPSS Statistics for Windows, Version 21.0. Armonk, NY: IBM Corp.).

\section{Systematic palaeobotany}

Order Cycadales Dumortier, 1829

Family Zamiaceae Horaninow, 1834

\section{Genus Zamia Linnaeus, 1763}

\section{Zamia nelliae Erdei \& Calonje sp. nov.}

Figures 2A-E, 3A-D

Holotype. - Inventory number UF 19531-70503 (STRI 36903), Florida Museum of Natural History (FLMNH); (Fig. 2A).

Type horizon and locality. - Gatuncillo Formation, middle Eocene to lower Oligocene. Buena Vista, Colon Province, Central Panama; locality numbered STRI loc. 290268; $9^{\circ} 16^{\prime} 4.80^{\prime \prime} \mathrm{N}, 79^{\circ} 41^{\prime} 15.83^{\prime \prime} \mathrm{W}$.

Etymology. - In honour of Nell Montgomery Jennings (19051990) who envisioned and established the Montgomery Botanical Center as a botanical research centre emphasizing palms and cycads.

Material. - Cuticle preparation: inventory number UF 19531-70503 (STRI 36903), stored at FLMNH.

Diagnosis. - Pinna lanceolate, tapering toward the apex; Apex acute; Margin entire; Venation parallel, veins closely spaced, more than twenty veins close to leaflet apex; Lamina hypostomatic; Stomata cyclocytic, in narrow bands of two to three ill-defined rows of stomata. Stomata arranged predominantly parallel, but often oblique or perpendicular to the long axis of the leaflet; Stomata isodiametric; Guard cells sunken surrounded by four to seven subsidiary cells; Abaxial ordinary epidermal cells parallel, elongated, in costal areas more elongated, anticlinals convex, non-angular; Adaxial ordinary epidermal cells parallel, elongated, linear, convex, non-angular with rounded corners; Rare one-celled trichome bases on both epidermis.

Description. - Lamina of the fragmentary leaflet is lanceolate, slightly asymmetrical and seems to be coriaceous (Fig. 2A). Preserved length and width of the lamina are 7 and $2.2 \mathrm{~cm}$, respectively. Less than half of the leaflet is preserved therefore the entire length and maximum width are estimated to be larger than $14 \mathrm{~cm}$ and $2.2 \mathrm{~cm}$. Apex is

Figure 2. Morphological details of Zamia nelliae Erdei et Calonje sp. nov. from the Paleogene of Panama (holotype, STRI 36903). Abbreviations: $\mathrm{lm}$ - transmitted light microscopy; SEM - scanning electron microscopy. A - leaflet showing entire margin and parallel venation. Scale bar $=1 \mathrm{~cm}$; $\mathrm{B}$ - adaxial cuticle displaying parallel arranged linear epidermal cells $(\mathrm{lm})$. Scale bar $=50 \mu \mathrm{m} ; \mathrm{C}-$ abaxial cuticle showing stomatal bands. Bands are composed of two-three ill-defined rows of stomata $(\mathrm{lm})$. Scale bar $=100 \mu \mathrm{m} ; \mathrm{D}$ - two stomatal bands with linear, parallel arranged epidermal cells between bands $(\mathrm{SEM})$. Scale bar $=100 \mu \mathrm{m} ; \mathrm{E}-$ closer view of a stomatal band. Some of the stomata are arranged obliquely or even perpendicularly to the band (SEM). Scale bar $=50 \mu \mathrm{m}$. 

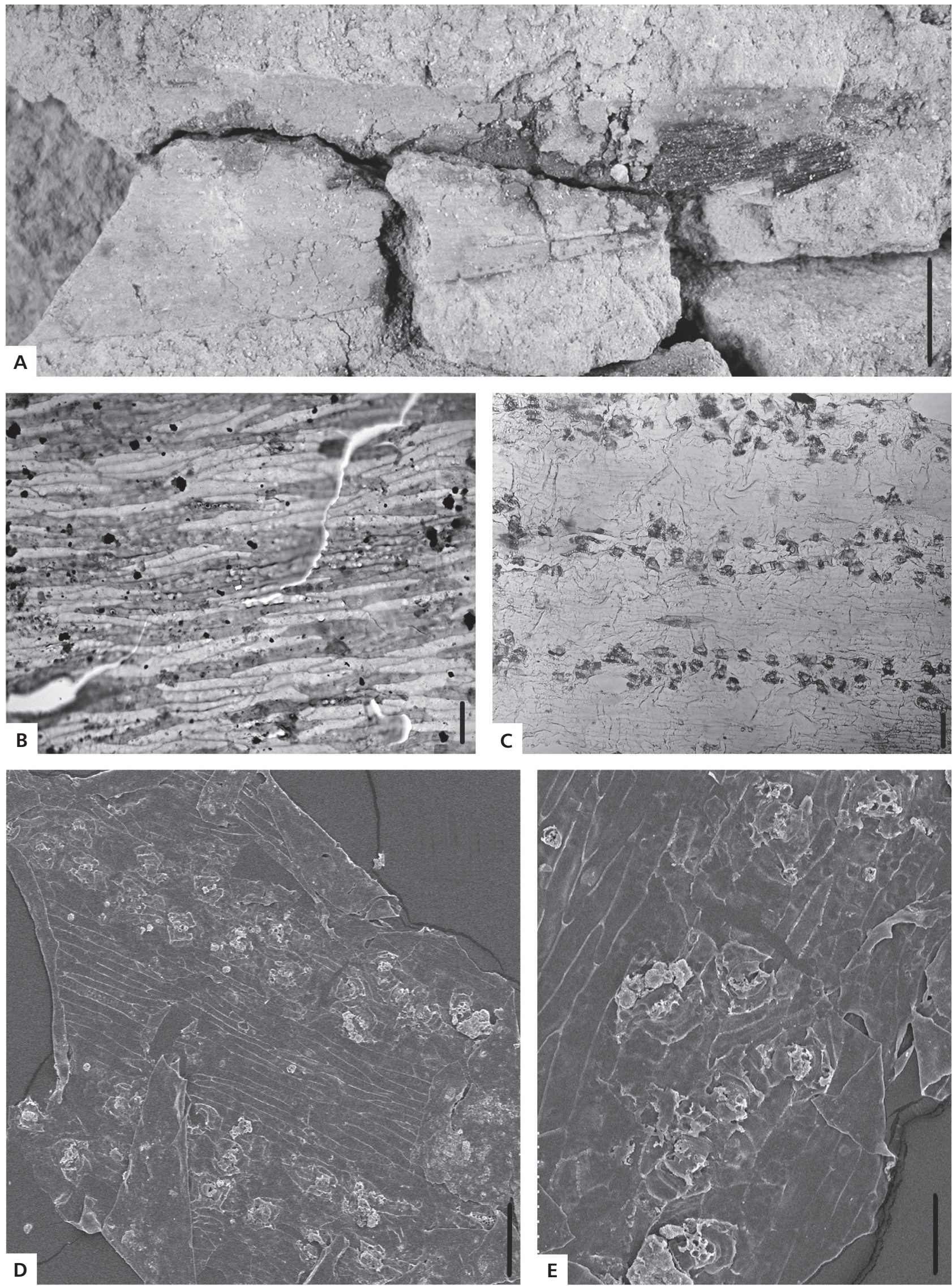
acute; base is not preserved. The margin is entire. Venation is parallel, with strong veins, spaced at $0.3-0.5 \mathrm{~mm}$ from each other measured in the apical part of the lamina. The number of veins is estimated about 25 near the apical part of the leaflet. No forkings or anastomoses of veins are observable. Veins seem to terminate at the margin (open venation).

Cuticle of both upper and lower surfaces is wellpreserved. On the adaxial cuticle ordinary cells are serially arranged, elongate, linear (Fig. 2B). Cells are of 75-250 $\mu \mathrm{m}$ in length and $10-20 \mu \mathrm{m}$ in width $(1 / \mathrm{w} \sim 7-12)$. Anticlinal walls are convex, non-angular, their corners are definitely rounded. The anticlinal cell walls seem to be uniformly thickened. The different staining of cell groups (Fig. 2B) may indicate variably thickened periclinal walls. On the abaxial cuticle ordinary cells are arranged parallel to the long axis of the lamina (Fig. 2C-E). Distinct costal and intercostal areas are differentiated. Cells in costal areas are elongate, linear, with similar dimensions as cells on the adaxial side, 60-230 $\mu \mathrm{m}$ long and 10-20 $\mu \mathrm{m}$ wide. Ordinary epidermal cells in intercostal areas are shorter. Stomata are cyclocytic (haplocheilic) and are arranged in bands (Figs 2C; 3A-D). Bands are mostly composed of two to three indefinite rows of stomata (Fig. 2C). Stomata are oriented variously, mainly parallel but often obliquely or even perpendicularly to the long axis of the leaflet (Fig. 2E). Stomata are broad oval, even rounded. Guard cells are 25-30 $\mu \mathrm{m}$ wide, $18-25 \mu \mathrm{m}$ long, seem slightly sunken and have strong thickened ledges (Fig. 3B-D). Stomatal pore is oval and $12-15 \mu \mathrm{m}$ long. Guard cells are surrounded by four to seven subsidiary cells organized more or less irregularly. One-celled trichome bases are rarely observable on both the abaxial and adaxial epidermis, on the former first of all in costal areas.

Discussion. - Comparison of Zamia nelliae with extant and extinct members of the Cycadales: The combination of macromorphological (lanceolate shape of the lamina, parallel veins of uniform order) and epidermal features of the fossil leaflet (elongate, non-isodiametric, slightly irregularly arranged ordinary epidermal cells of the adaxial and abaxial epidermis, cyclocytic type of stomata, thickened dorsal ledges of guard cells, irregular pattern of subsidiary cells, stomata arranged in bands) seen in this fossil lamina resembles the features of modern cycads. Extinct cycad genera hitherto described from the Cenozoic and established on fossil foliage (having both macro- and micromorphological details), e.g. Austrozamia Wilf, D. Stevenson et Cuneo (Wilf et al. 2016), Ctenis Lindley et Hutton (Erdei \& Manchester 2015), Dioonopsis Horiuchi et Kimura (Horiuchi \& Kimura 1987, Erdei et al. 2012), Eostangeria Barthel (Barthel 1976; Palamarev \& Uzunova 1992; Kvaček, Z. \& Manchester 1999), Pseudodioon Erdei, Akgün et Barone Lumaga (Erdei et al. 2010), Pterostoma R. S. Hill (Hill 1980), have isodiametric ordinary epidermal cells contrasting the linear cells of the epidermis of Z. nelliae. Stomata of the fossil cycads mentioned above (excluding Austrozamia since lacking information on stomata) display a more regular arrangement of the subsidiary cells than those of the fossil from Panama. Ctenis, Dioonopsis, and Pterostoma all have scattered, randomly arranged stomata definitely contrasting the distinct stomatal bands of the fossil described here. In Pseudodioon stomata are arranged in bands however guard cells are surrounded by much higher number of subsidiaries (8-11) than in the fossil from Panama. As regards macromorphology, the venation of most of the above extinct cycads differs from that of Zamia nelliae in displaying forkings and anastomoses of veins (Ctenis, Dioonopsis, Pterostoma) or having a midrib (Eostangeria).

Mesozoic foliage assigned to cycads (or cycadophytes) differs either in macro- (leaflet/pinna shape, venation) or micromorphology (epidermal cells, arrangement of stomata) or in both, e.g. Almargemia Florin (Florin 1933) - stomata irregularly arranged, sunken guard cells; Apoldia Wesley (Zijlstra et al. 2009, Kustatscher et al. 2010) - pinna shape, isodiametric epidermal cells; Ctenis Lindley et Hutton (Lindley \& Hutton 1834) - anastomosing veins, isodiametric epidermal cells, scattered stomata; Eobowenia M. Coiro et C. Pott (Coiro \& Pott 2017) - short rows of heavily cutinised epidermal cells; Jirusia Bayer (Kvaček, J. 1995) isodiametric epidermal cells; Mesenea Kvaček (Kvaček, J. 1999) - venation, isodiametric epidermal cells, scattered stomata; Mesodescolea Archangelsky (Archangelsky \& Petriella 1971, Artabe \& Stevenson 1999) - pinna shape, epidermal cells; Mesosingeria Archangelsky (Archangelsky 1963, Villar de Seoane 2005) - pinna/pinnule morphology

Figure 3. Stomatal details of Zamia nelliae Erdei et Calonje sp. nov. from the Paleogene of Panama (holotype, STRI 36903) and epidermal anatomy of extant Ceratozamia Brongn. species for a comparison. Abbreviations: $1 \mathrm{~m}$ - transmitted light microscopy; SEM - scanning electron microscopy. • A - closer view of a stomatal band of Zamia nelliae with a stoma arranged perpendicularly to the band axis. Epidermal cells in stomatal bands are less elongated than cells between the bands $(1 \mathrm{~m})$. Scale bar $=50 \mu \mathrm{m}$; B - two stomata of Zamia nelliae showing sunken guard cells and well developed cuticular ledges $(\mathrm{lm})$. Scale bar $=50 \mu \mathrm{m} ; \mathrm{C}-$ stoma of Zamia nelliae enlarged showing cyclocytic arrangement of subsidiaries $(\mathrm{SEM})$. Scale bar $=$ $30 \mu \mathrm{m}$; D - stoma of Zamia nelliae enlarged showing well developed cuticular ledges (SEM). Scale bar $=30 \mu \mathrm{m}$. $\bullet$ E - abaxial epidermis of Ceratozamia microstrobila Vovides et J.D. Rees showing a stomatal band. Note the parallel arranged stomata and the rows of short cells (indicated by arrow), MBC 931220A $(\mathrm{lm})$. Scale bar $=50 \mu \mathrm{m} ; \mathrm{F}$ - adaxial epidermis of Ceratozamia microstrobila showing parallel arranged elongate cells and rows of short cells (indicated by arrow), MBC 931220A $(\mathrm{lm})$. Scale bar $=50 \mu \mathrm{m} . \bullet \mathrm{G}-$ abaxial epidermis of Ceratozamia sabatoi Vovides, Vázq. Torres, Schutzman et Iglesias. Note the parallel arranged stomata and the rows of short cells (indicated by arrow), MBC 20010176 (lm). Scale bar $=50 \mu \mathrm{m}$; $\mathrm{H}-\mathrm{adaxial}$ epidermis of Ceratozamia sabatoi showing parallel arranged elongate cells and rows of short cells (indicated by arrow), MBC $20010176(\mathrm{~m})$. Scale bar $=50 \mu \mathrm{m}$. 

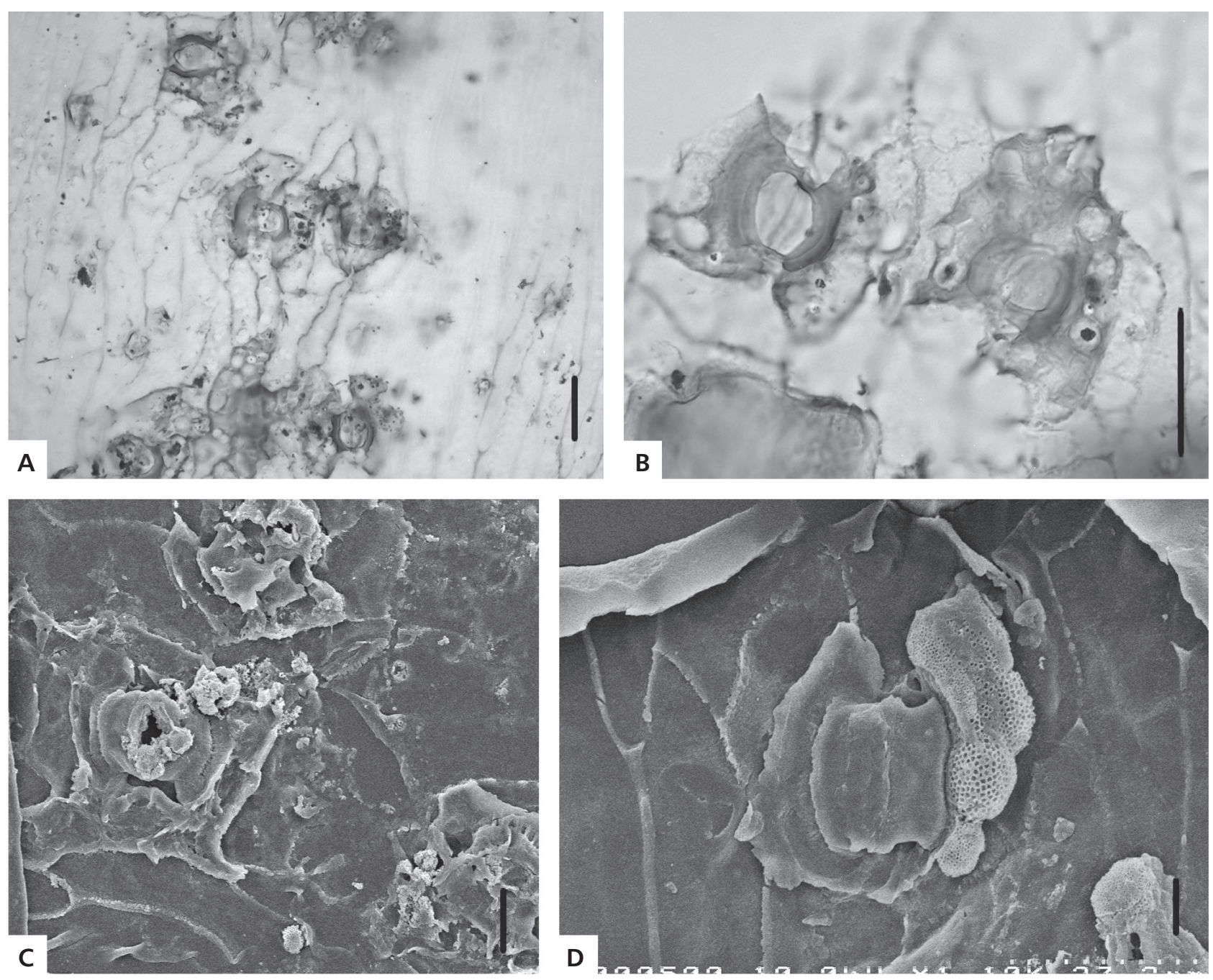

$2 \sqrt{3}$

\section{है}

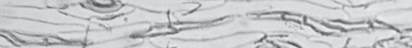

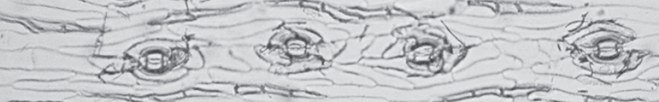

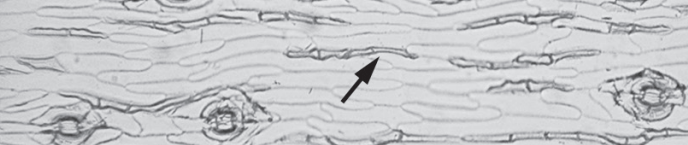

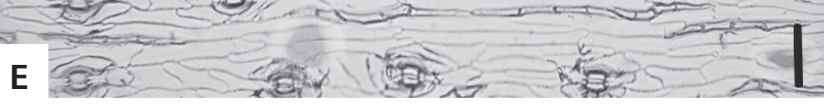

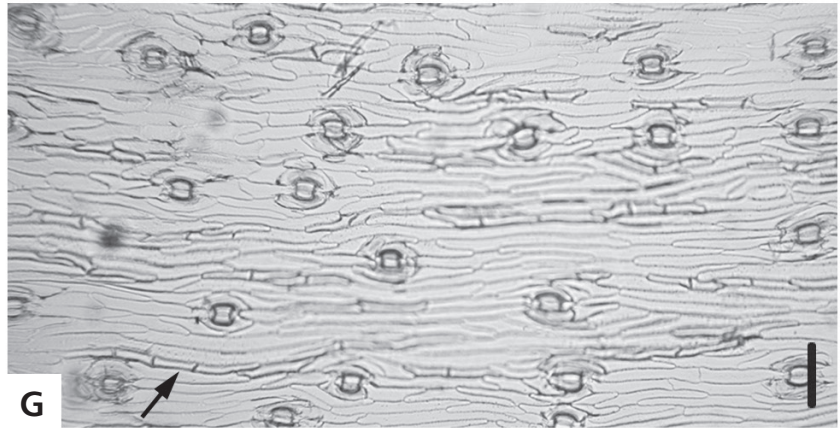

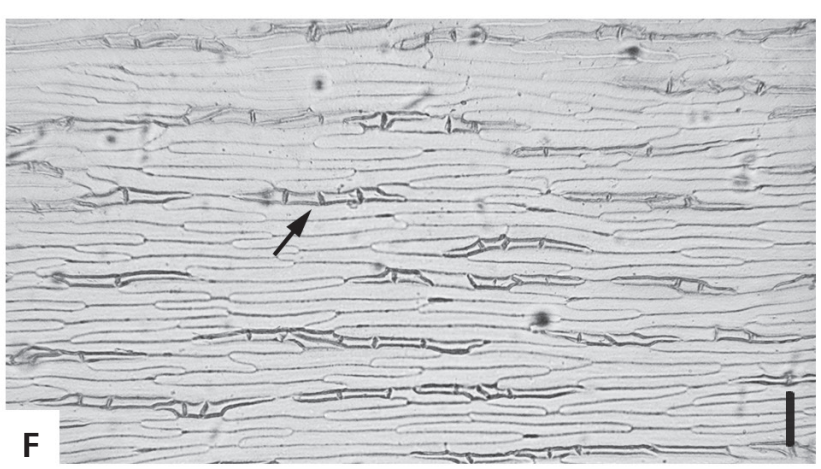


(shape), isodiametric epidermal cells, scattered, deeply sunken stomata; Nilssonia Brongniart (Brongniart 1825; Harris 1964; Kvaček, J. 1995; Watson \& Cusack 2005; Pott et al. 2007a, 2012) - venation, scattered stomata; Pseudoctenis Seward (Seward 1911, Pott et al. 2007b) - isodiametric epidermal cells; Restrepophyllum Passalia, Del Fueyo et Archangelsky (Passalia et al. 2010) - pinna morphology (shape, venation), isodiametric epidermal cells, scattered stomata; Sueria Menéndez (Menéndez 1965) - pinna shape, epidermal cells; Ticoa (Archangelsky 1963, Villar de Seoane 2005) - pinna morphology (shape, venation), isodiametric epidermal cells, scattered, deeply sunken stomata.

Macro- and micromorphology of the fossil leaflet recalls genera of the Zamiaceae - first of all those of the Zamioideae. In Cycadaceae, species of Cycas develop leaflets with a midrib but no other veins. As regards genera in Zamiaceae, Stangeria T. Moore (also having midrib) is well-known for its feather-like venation. Bowenia develops broader and shorter leaflets than the fossil, and the anticlinal walls of its epidermal cells show a concave, angular pattern and stomata are non-sunken (see also Coiro \& Pott 2017). Members of subfamily Encephalartoideae, i.e. Dioon, Encephalartos, Macrozamia and Lepidozamia species, develop leaflets which are usually elongate (all the above genera) or even linear (Macrozamia, Lepidozamia), and epidermal cells do not display the linear arrangement shown by the fossil. Anticlinal walls of the epidermal cells in Dioon show a definite concave, angular pattern and stomata are deeply sunken (see in Greguss 1968, Erdei et al. 2010, Barone Lumaga et al. 2015). In the other three genera epidermal cells are not of the linear type as in the fossil and anticlinal cell walls show a more pronounced concave pattern. In Encephalartos and Lepidozamia the long axis of epidermal cells is frequently oblique to the veins (this is also well observable in the extinct genus Austrozamia, assigned to the Encephalartoideae, Wilf et al. 2016), cells of triangular shape occur, and epidermal cells are usually non-elongate ( $1 / \mathrm{w}$ less than $5-7)$ displaying a distinct concave pattern (Greguss 1968, Hill 1980). In Macrozamia anticlinal walls of epidermal cells display a concave pattern, stomata are parallel to the long axis of leaflet, and encircling/subsidiary cells give an angular (pentagonal, hexagonal) outline of the stomatal pore (see Greguss 1968, Carpenter 1991), unlike our fossil.

Members of subfamily Zamioideae, i.e. Ceratozamia, Microcycas (Miq.) A. DC. and Zamia develop leaflets with epidermal details more comparable to the fossil (Figs $3 \mathrm{E}-\mathrm{H}, 4 \mathrm{~A}-\mathrm{H}$ ) however species of the first two genera can be easily distinguished from the fossil. The single species of Microcycas has quite elongate, linear leaflets unlike the fossil. As regards epidermal details, cells with heavily thickened walls form rows (Fig. 4B) unlike in the fossil. Stomata are arranged parallel to the long axis of the leaflet in Ceratozamia (Fig. 3E, G), and Microcycas (Fig. $4 \mathrm{~A}$ ), unlike the often obliquely arranged stomata of the fossil. In contrast, numerous Zamia species display stomata oriented obliquely (e.g. Z. erosa O. F. Cook \& G. N. Collins, Z. pumila L., Z. stricta Miq., etc.) or even perpendicular (e.g. Z. dressleri D. W. Stev., Z. urep B. Walln., Z. wallisii A. Braun) to the long axis of the leaflet (Fig. 4C, E, G). Stomata of Microcycas are more elongate (longer than wide), than those of the fossil and of modern Zamia species (Fig. 4A; see also Greguss 1968).

In Ceratozamia stomatal bands are broad; practically stomata are dispersed in intercostal areas between the veins. However, the most obvious distinctive character is the occurrence of serial rows of short cells with heavily thickened cell walls on both the adaxial and abaxial epidermis of leaflets in species of Ceratozamia (Fig. 3E-H) (see also Greguss 1968); these are absent in species of Zamia as well as in the fossil (Fig. 4C-H). The significance of short cell rows in identifying Ceratozamia is also supported by its fossil remains. Rows of short cells similar to those of modern Ceratozamia species were observed in leaves of the genus described from Europe, i.e Ceratozamia floersheimensis (Engelhardt) Kvaček, Z. from early Oligocene sites in Germany, Hungary and Slovenia (Kvaček, Z. 2002). Darker staining cell groups occur on the adaxial cuticle of the fossil (Fig. 2B) showing similarity to some modern Zamia species (Fig. 4H). However the importance of this trait is subordinate since possibly occurring in other cycad genera, as well (e.g. Macrozamia; Greguss 1968, Carpenter 1991).

Based on the above considerations and the highly comparable epidermal details and macromorphological traits of the fossil and modern Zamia species we assign the fossil leaflet to Zamia.

Morphometric analysis of epidermal traits of modern Zamia species and the fossil Z. nelliae: Morphometric analysis of the epidermal details of modern Zamia species (35 samples including 32 species) and the fossil species, Z. nelliae was carried out to assess the morphological

Figure 4. Epidermal anatomy of extant species of Microcycas (Miq.) A. DC. and Zamia L. for a comparison. Abbreviation: lm - transmitted light microscopy. • A - abaxial epidermis of Microcycas calocoma (Miq.) A. DC. showing a stomatal band, MBC RM384A (lm). Note the parallel arrangement of stomata. Scale bar $=50 \mu \mathrm{m}$; B - adaxial epidermis of Microcycas calocoma with slightly elongated but not linear cells, MBC RM384A $(1 \mathrm{~m})$. Scale bar $=50 \mu \mathrm{m} . \cdot$ C - abaxial epidermis of Zamia erosa O.F. Cook et G.N. Collins showing stomatal bands, MBC 20030275D (lm). Note the small-sized stomata and some stomata arranged obliquely. Scale bar $=100 \mu \mathrm{m} ; \mathrm{D}-$ adaxial epidermis of Zamia erosa showing elongate cells, MBC $20030275 \mathrm{D}(\mathrm{lm}) . \mathrm{Scale}$ bar $=100$ $\mu \mathrm{m}$. $\cdot$ E - abaxial epidermis of Zamia pumila L. showing stomatal bands, MBC 20080285B (lm). Note the sometimes obliquely arranged, small-sized stomata. Scale bar $=100 \mu \mathrm{m} ; \mathrm{F}-$ adaxial epidermis of Zamia pumila showing elongate cells. Scale bar $=100 \mu \mathrm{m} ; \mathrm{G}-\mathrm{closer}$ view of stomata of Zamia pumila, MBC 20080285B (lm). Scale bar $=50 \mu \mathrm{m} ; \mathrm{H}$ - closer view of adaxial epidermis of Zamia pumila, MBC $20080285 \mathrm{~B}(\mathrm{~lm})$. Scale bar $=50 \mu \mathrm{m}$. 

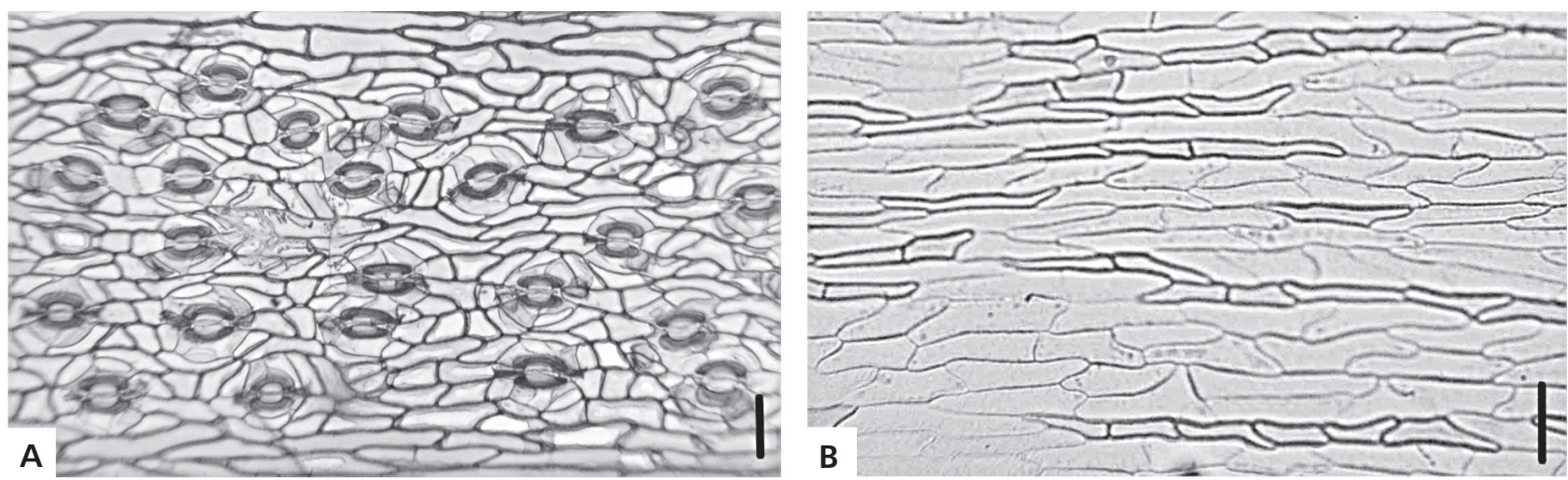
(D)
(5) $\int \sqrt{10}$
है क्षेत
(2)
(20)

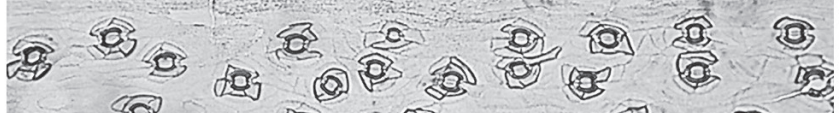

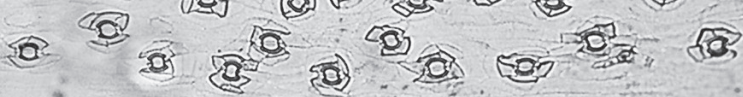

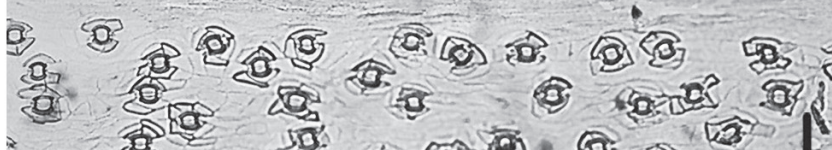

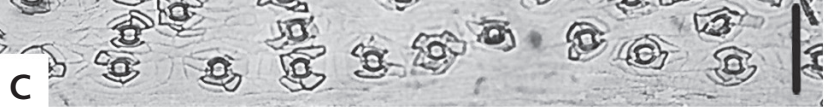
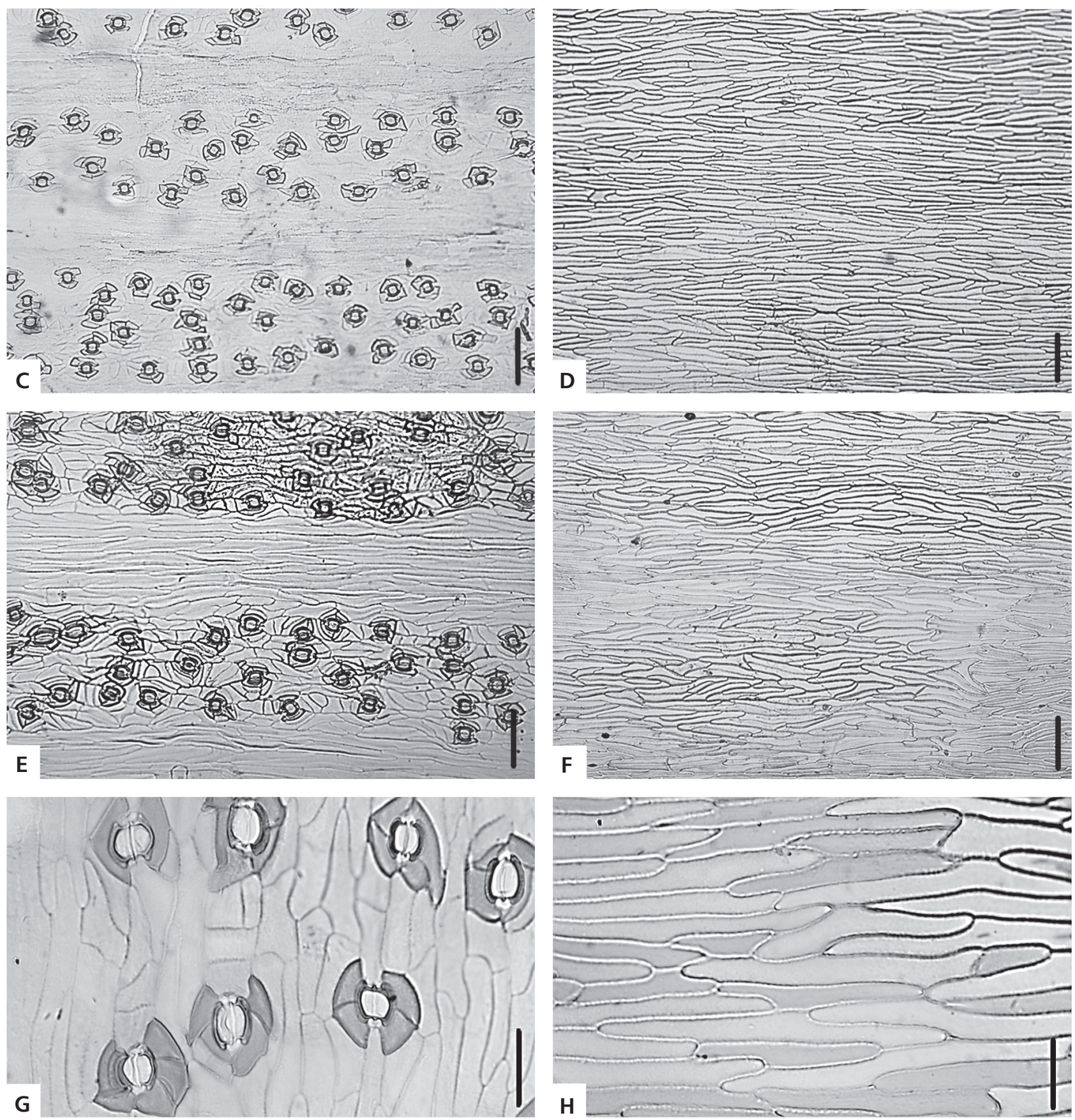
Table 2. Variance from PCA analysis of Zamia epidermal traits.

\begin{tabular}{cccc}
\hline \multirow{2}{*}{ Component } & \multicolumn{3}{c}{ Initial Eigenvalues } \\
\cline { 2 - 4 } & Total & \% of Variance & Cumulative \% \\
\hline 1 & 6.133 & 43.806 & 43.806 \\
2 & 2.487 & 17.764 & 61.571 \\
3 & 1.978 & 14.125 & 75.696 \\
4 & 1.011 & 7.222 & 82.918 \\
\hline
\end{tabular}

similarity and relation of the fossil to the modern members of the genus. Results of the first two components of the principal coordinate analysis (PCA) are shown in Figure 5 . The first and second components of the PCA explain $43.81 \%$ and $7.76 \%$ of the variance, respectively (Tab. 2). Values of the various variables estimated for the fossil epidermal cells are within the range represented by extant Zamia species. Species of the Caribbean clade are obviously grouped together thus demonstrating a definite uniformity as regards their epidermal traits. The epidermal details of Z. nelliae show the highest similarity to species belonging to the Caribbean clade. Most members of this clade possess small, relatively high number of stomata and small-sized epidermal cells. Among species of this clade, Z. erosa is most comparable to the fossil; similarities include stomatal and interstomatal band widths and ratios, adaxial cell shape. The Z. erosa sample was collected from a plant of Puerto Rican provenance, but the species is also currently considered to occur in Jamaica and Puerto Rico. Other members of this clade displaying definitely elongate, or even linear epidermal cells are Z. integrifolia L.f., Z. pumila, Z. portoricensis Urb., and Z. stricta (Fig. 4C-H).

\section{Review of previously published fossil reports of Zamia}

Most of the specimens assigned formerly to Zamia are cited here as "Zamia" to indicate that these botanical assignments are either not proven or false. The specimens are either devoid of enough diagnostic traits to identify them as a species of Zamia or undoubtedly do not represent the Zamia genus (or even cycads). It should be noted, however, that all the specimens re-examined are too poorly preserved to identify them with certainty.

Order Cycadales Dumortier, 1829

Family Zamiaceae Horaninow, 1834

\section{?Zamia collazoensis Hollick, 1928}

1928 Zamia collazoensis; Hollick, p. 184, pl. 53, figs 1 (type), 3, 5, (7?).
1932 Zamia collazoensis Hollick. - Hollick, p. 173, pl. 7, figs 5,6 .

Remarks. - Hollick (1928) established two Zamia species from the Paleogene Collazo Shales of Puerto Rico and distinguished them on the basis of the shape of the lamina. Z. collazoensis was established for broader and more rounded leaflets. Based on macromorphological details Hollick's two species may be conspecific. All the specimens figured by Hollick were re-examined. The poorly preserved foliage fragments showing faintly observable macromorphological details, i.e. entire margin and parallel venation, provided heavily coalified cuticles with no cellular details preserved. Although the fossils themselves provide not such clear-cut morphological details as implied by the diagrams of Hollick, the fossils may represent Zamia leaflets based on their shape, venation (and cuticular details given below for ?Z. noblei).

\section{?Zamia noblei Hollick, 1928}

Figure $6 \mathrm{~A}-\mathrm{C}$

1928 Zamia noblei; Hollick, p. 185, pl. 53, figs 9, 10, pl. 54, figs $1,3 \mathrm{a}$ (type), pl. 55, figs 1-3, 4a, 5a.

1932 Zamia noblei Hollick. - Hollick, p. 174, pl. 6, figs 3, 4.

Remarks. - Hollick's other Zamia species from Puerto Rico is distinguished by its slender leaflets. Cuticular details were preserved on one leaflet from among the specimens figured by Hollick (1928: pl. 55, fig. 1, YPM27152; Fig. 6A). A fragment of the abaxial cuticle shows elongate, somewhat irregular ordinary epidermal cells (Fig. 6B, C) and a stomatal band constructed of 4 ill-defined rows of stomata. Stomatal structure, though faintly observable, seems to be of cycadalean, cyclotypic type. The adaxial cuticle is not preserved. The overall cuticular structure suggests a zamiaceous cycad; the lack of short cell rows and the slightly irregular arrangement of stomata are consistent with Zamia. However due to poorly preserved cuticular details and the lack of adaxial cuticle we are unable to confirm that the leaflets are Zamia.

\section{"Zamia" coloradensis (Knowlton) Brown, 1962} Figure 6D

1962 Zamia coloradensis; (Knowlton) Brown, p. 47, pl. 10, figs 6,9 .

Remarks. - Brown (1962) described two Zamia species from the flora of Wyoming (Paleocene, Fort Union Formation). Some of the specimens had previously been assigned by Brown (1939) to Podozamites latipennis Heer but Brown concluded later (1962) based on new collections that the fossils represent the genus Zamia, and made a new combination Zamia coloradensis. Knowlton (1930: p. 40, 
Figure 5. Principal coordinate analysis results of Zamia epidermal characters. The epidermal morphology of extant Zamia species and of the fossil Z. nelliae were analyzed. Major Zamia clades (the component species of major clades are indicated in Tab. 1) are indicated by different symbols. Data points represent species and are indicated by the symbol of the clade the species belongs to. Values of the various variables estimated for the epidermal cells of the fossil $Z$. nelliae are within the range represented by extant Zamia species. The epidermal details of $Z$. nelliae show the highest similarity to species belonging to the Caribbean clade.

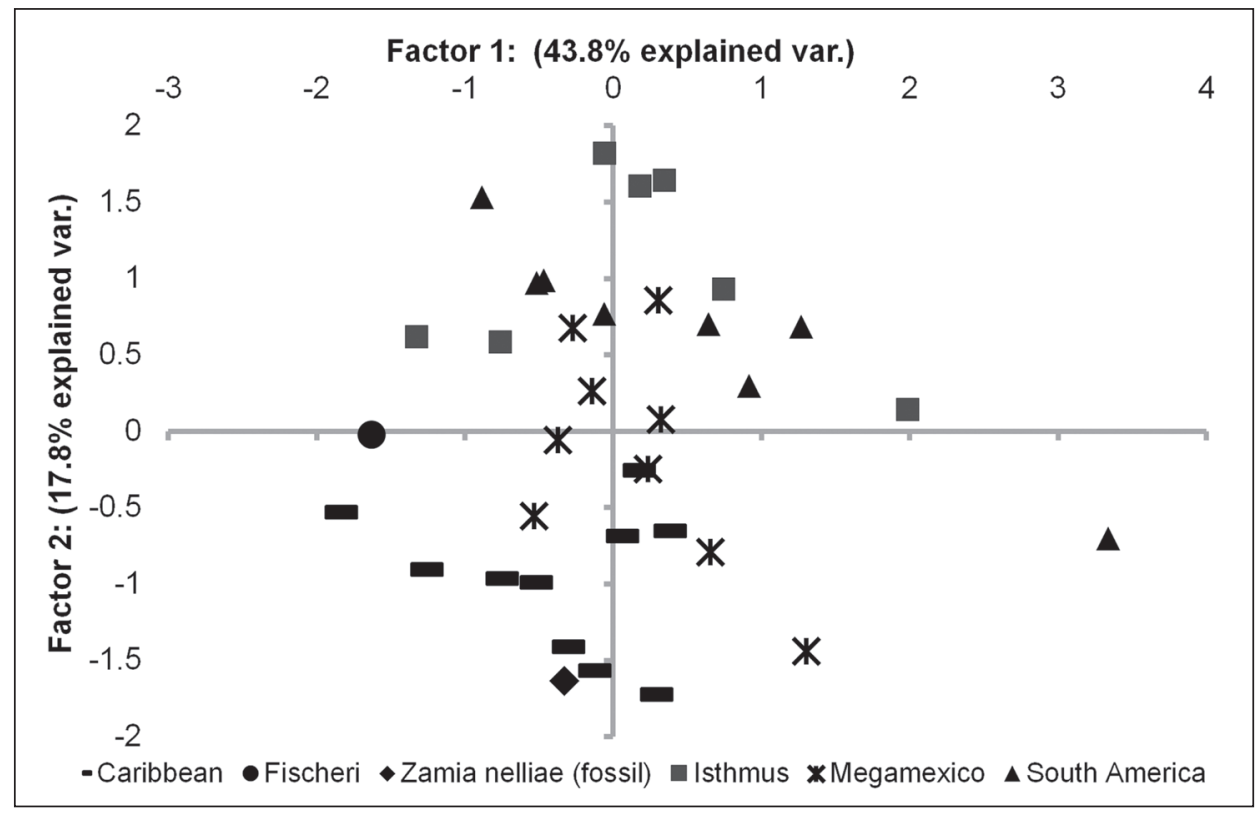

pl. 10, fig. 3) had assigned a specimen, collected by George L. Cannon, in 1889, from Middle Park Formation, Colorado, to the palm genus Chamaedorea?, as Chamaedorea? coloradensis Knowlton, however Brown noted (1962) that this, as well as the other cited remains, do not represent palms owing to the forkings and anastomoses of veins. For a discussion see "Zamia" wyomingensis below.

\section{"Zamia" wyomingensis Brown, 1962}

Figure 6E

1962 Zamia wyomingensis; Brown, p. 47, pl.10, fig.1.

Remarks. - The other species established by Brown (1962) from the Paleocene flora of Wyoming, "Zamia" wyomingensis, was based on a specimen from the same strata as "Z." coloradensis. The reinvestigation of the type specimens of "Z." wyomingensis and "Z." coloradensis showed that these do not represent extant Zamia (see also Watt 1971, Manchester 2014). The specimens may represent a group of extinct cycads related to Ctenis or Dioonopsis based on characteristic anastomoses of veins shared by these extinct taxa (Erdei et al. 2012, Erdei \& Manchester 2015). The specimen of " $Z$." wyomingensis shows just the basal part of leaflets therefore details on leaflet venation from the apical region are not available. It should also be noted that the leaflet bases of the specimen of "Z." coloradensis figured by Brown (1962: pl.10, fig. 9; Fig. 6D herein) show a somewhat distorted character and are not clearly observable. None of the reinvestigated specimens have epidermal details preserved which could help a more precise identification. It may also be assumed that the fossil described by Knowlton as Chamaedorea? is related to these extinct cycads as well, however Knowlton's figure (1930: pl. 10, fig. 3) seems to indicate a specimen different from those figured in Brown (1962), and the figure itself does not allow the proper reassessment of the specimen. Nevertheless, Brown (1962) referred to the specimen as possessing vein forkings and anastomoses similarly to Brown's "Zamia” species.

\section{"Zamia" (?) wilcoxensis Berry, 1916}

Figure 6F

1916b Zamia (?) wilcoxensis; Berry, p. 169, pl. 114, fig. 2. 1932 Zamia (?) wilcoxensis Berry. - Hollick, p. 173, pl. 6, fig. 6.

Remarks. - Berry described "Z." (?) wilcoxensis Berry (1916b) from the Eocene Wilcox flora of Louisiana in the SE United States. The species was established on the basis of a poorly preserved impression. The holotype is a basal portion of a linear, entire-margined leaflet with parallel, uniform order of veins which recalls leaflets in Zamiaceae. The base of the leaflet is comparable to the morphology observable among cycads with non-articulated leaflets (Encephalartoideae D. W. Stev.).

?Order Cycadales

"Zamia" tennesseeana Berry, 1930

Figure 6G

1930 Zamia tennesseeana Berry; Berry, p. 51, pl.32, fig. 8.

1932 Zamia tennesseeana Berry. - Hollick, p. 173, pl. 13, fig. 4. 
Remarks. - Berry described another species, "Z." tennesseeana Berry (Berry 1930) from the Eocene Wilcox flora (SE United States). The holotype of this species seems to be comparable to zamiaceous leaflets based on its gross morphology, i.e. linear lamina, entire margin and parallel, uniform order of veins. Berry (1930) noted that he hesitated to relate it to the modern Nageia (Podocarpaceae) which has somewhat similar leaves. Hollick (1932) accepted Berry's identifications and cited the modern counterparts proposed by Berry and also added other Zamia species for comparison. Cuticular details, which would be required to verify cycadalean affinity are not preserved.

\section{"Zamia" washingtoniana Ward, 1985}

Figure $6 \mathrm{H}$

1895 Zamia washingtoniana; Ward, p. 349, pl. 2, fig. 6.

1905 Zamia washingtoniana Ward. - Fontaine, p. 503, pl. 111, figs $1,2$.

1911 Zamites tenuinervis Fontaine. - Berry, p. 345, pl. 54, fig.1.

Remarks. - Ward (1895) established Zamia washingtoniana based on a leaf and a seed-like remain preserved on the same slab from the Mount Vernon flora (Potomac Formation, Cretaceous).

Fontaine (1905) mentioned that 11 specimens altogether could be assigned to this species and figured two of the specimens. Later Berry (1911) synonymized Ward's species in Zamites tenuinervis Fontaine, however pinnae in Zamites Brongniart are attached to the upper surface of the rachis which trait is not traceable in Ward's specimens (only fragmentary pinnae/leaflets). The type specimens reinvestigated here (two specimens with counterparts; figured on pl. 111, figs 1, 2 in Fontaine 1905) are entire margined linear leaflets with parallel venation which is comparable to most cycads in the Zamiaceae. Since epidermal details are not preserved, the systematic relationship of the foliage cannot be supported.

\section{"Zamia" sp. Berry, 1929}

1929 Zamia sp.; Berry, p. 2, pl. 1, fig. 6.

Remarks. - Berry (1929) assigned a leaf fragment from Tertiary deposits of Colombia (from sandstones associated with coal at Montserrat near Bogota) to Zamia. Berry's figure shows the basal fragment of a parallel-veined leaf(let) which may belong to a cycad but epidermal details are not available for a precise identification.

Other unidentified remains

\section{"Zamia" australis Berry, 1928}

1928 Zamia australis; Berry, p. 11, pl. 2, fig. 1.
1932 Zamia australis Berry. - Hollick, p. 176, pl. 6, fig. 2.

Remarks. - Berry described "Zamia" australis Berry from Rio Negro, Argentina. Although Hollick (1932) accepted Berry's identification, the reinvestigation of the holotype specimen done by the first author (BE) did not reveal evidence of a cycad affinity. It appears to be a poorly preserved unidentifiable foliage fragment.

\section{"Zamia praecedens" Ett.}

1903 Zamia praecedens Ett. - Krasser, p. 853. [nomen nudum]

Remarks. - Krasser (1903) mentioned a new species by Ettingshausen, "Zamia" praecedens in his work on the fossil flora from Ouricanga, Brasil, however the species was not validly published since no description or figure of the specimen was included. Berry (1928: p.11) noted that the putative Zamia ("Z." praecedens Ett. nomen nudum) from Krasser (1903) was not represented in the collection he obtained later from the locality in Brasil. The specimen which is currently stored in the Natural History Museum, Wien (NHMW1905/0017/0004) is an impression fossil without cuticle preserved. Although, at first glance the fossil shows cycad characters, i.e. entire margined, linear leaf(let) and parallel venation, it seems to have at least two order of veins which contrasts cycads having a uniform order of veins.

\section{Specimen revisions published in earlier works}

Some of the fossil specimens formerly assigned to the genus Zamia were reviewed and revised in earlier works. Erdei et al. (2012) investigated specimens of "Zamia" mississippiensis Berry described from the Eocene Wilcox flora, SE United States (Berry 1916a: p. 177, fig. 1.; 1917: p. 63, fig. 17; Hollick 1932: p. 173, pl. 6, fig. 1a-c). The re-examination of Berry's type specimens from Meridian, Mississippi, indicated that they are coniferous twigs, probably Taxodioid Cupressaceae (Erdei et al. 2012). The occasionally forking parallel veins mentioned by Berry (1916a) are not observable on the poorly preserved specimens. Leaflets from the Eocene flora of La Porte, California were assigned by Potbury (1935) to Zamia and were identified as a variety of Berry's species, "Z." mississippiensis Berry var. macrophylla Potbury (Potbury 1935: p. 60, pl. 1, fig. 7). However, the leaflets, with well-preserved epidermal characters, were reassigned by Erdei et al. (2012) to an extinct cycad genus as Dioonopsis macrophylla Erdei, Manchester et Kvaček, Z.

"Zamia" tertiaria Engelhardt (1891: p. 646, pl. 2, fig. 16) was described on the basis of a single fragmentary leaf from the Eocene of Coronel, Chile. Unfortunately, as Wilf et al. (2014) noted, the holotype of the species has been lost along 

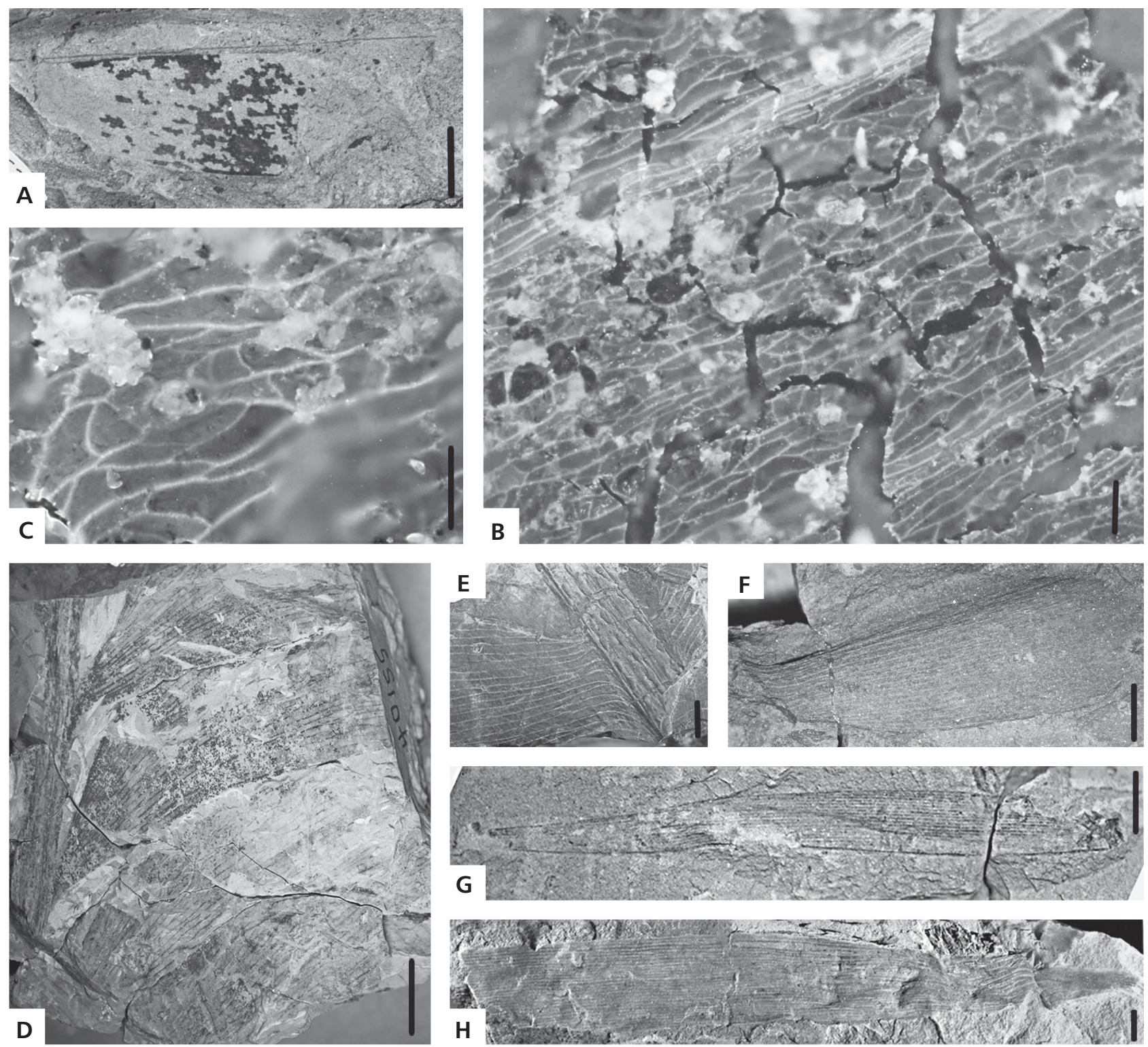

Figure 6. Fossil specimens described formerly as Zamia and re-examined in the scope of this study. Abbreviation: fm - fluorescence microscopy. • A, B, C- ?Zamia noblei; A - foliage fragment of ?Zamia noblei Hollick from the Paleogene of Puerto Rico, (YPM27152), scale bar =1 cm; B - abaxial cycadalean type cuticule of ?Zamia noblei showing stomatal bands, (YPM27152), fm, scale bar $=50 \mu \mathrm{m}$; C - closer view of a stoma of ?Zamia noblei displaying cyclocytic arrangement of subsidiary cells, (YPM27152), fm, scale bar $=50 \mu \mathrm{m} . \bullet \mathrm{D}-$ leaf fragment of "Zamia" coloradensis (Knowlton) Brown from the Paleocene flora of Wyoming. Note the cycadalean type leaf and leaflets inserted laterally on rachis, (USNM40155/type), scale bar $=1 \mathrm{~cm}$. E - leaf fragment of "Zamia" wyomingensis Brown from the Paleocene flora of Wyoming showing leaflets inserted with a broad base on rachis, (USNM167487/holotype), scale bar $=0.5 \mathrm{~cm} . \bullet \mathrm{F}$ - leaflet fragment of "Zamia" wilcoxensis Berry described from the Eocene Wilcox flora, (USNM35474), scale $\mathrm{bar}=0.5 \mathrm{~cm}$. Note the broad base of the leaflet. $\bullet \mathrm{G}-$ foliage fragment of "Zamia" tennesseeana Berry from the Eocene Wilcox flora showing parallel venation, (USNM39727), scale bar $=0.5 \mathrm{~cm} . \cdot \mathrm{H}$ - foliage fragment of "Zamia" washingtoniana Ward from the Cretaceous Mount Vernon flora showing parallel venation, (USNM31768), scale bar $=0.5 \mathrm{~cm}$.

with many other specimens from Engelhardt's monograph (see Wilf et al. 2014 for a detailed discussion on the topic). The drawing of the holotype does not give definite clues to identify the leaf fragment with certainty as a cycad.

Wilf et al. (2014) reinvestigated some of the specimens assigned by Berry (1922: p. 120, pl. 1, fig. 4, pl. 2, figs 1-3) to "Zamia" tertiaria from Chile (Arauco Mine, Curanilahue) and stored in the Smithsonian Institution (USNM 320640-43). The authors noted that the foliage remains are somewhat different from the drawings (which show densely packed, parallel, occasionally forking veins) and display monocot features including at least two order of veins.

Berry (1922: p. 120) assigned another specimen to "Zamia" tertiaria from Engelhardt's monograph (1891: 
p. 686 , pl. 1, fig. 4) that was originally identified by Engelhardt as a monocot remain. Nevertheless, the cycad affinity of foliage remains published by Engelhardt (1891) and Berry (1922) had already been discussed by Hollick (1932: p. 175) and subsequently by Wilf et al. (2014).

Specimens described and figured as "Zamia" tertiaria Engelhardt by Berry (1938: p. 57, pl. 9, USNM 40378h; pl. 8, figs 4, 5, USNM 40378d, f ) alongside with the historical collection of "Zamia" tertiaria from the Eocene Río Pichileufú flora of Río Negro Province, Argentina and stored in the Smithsonian Institution were reinvestigated by Wilf et al. (2014) and assigned to Agathis (A. zamunerae Wilf) demonstrating the first record of the genus from South America. The authors recovered numerous additional specimens recalling Berry's "Zamia" tertiaria from sites in Río Pichileufú and Laguna del Hunco, including leafy branches and twigs however, as stated by the authors, with such a high relative abundance which is highly unlikely in the case of a cycad. Furthermore, the twigs showed terminal buds and decussate phyllotaxy suggesting a conifer with simple leaves, not a pinnate cycad leaf (Wilf et al. 2014).

\section{Conclusions}

The review presented herein leads us to conclude that fossil specimens formerly assigned to Zamia either show characters not shared by modern Zamia species or suffer from poor preservation hindering proper identification of the genus. The fossil foliage from Paleogene sediments in Panama, described here as Zamia nelliae, represents the first convincing fossil evidence of Zamia. Thus, species representing Zamia must have appeared by the end of the Eocene or earliest Oligocene. If Hollick's fossils from Puerto Rico, ?Z. collazoensis and ?Z. noblei, do represent the genus Zamia then the distribution and probable diverse occurrence of the genus (the specimens from Puerto Rico are clearly distinct from $Z$. nelliae) may be postulated in the Caribbeanen-Central American region by the Oligocene.

The morphometric analysis of epidermal micromorphology of 32 modern and the fossil Zamia species showed high similarity of the fossil epidermal traits with those of the Caribbean species group. As most members of the Caribbean clade share epidermal details and form a group more or less distinct from species belonging to other Zamia clades, grouping of the fossil with the Caribbean clade may imply a phylogenetic relationship.

The palaeogeographic settings of the Panama isthmus, the Caribbean and northern South America during the Paleogene are of pivotal importance in assessing the early evolution of Zamia. Paleogeography and biogeography of Central America and the Caribbean are highly complex issues and tectonic history of this region is still far from settled. The evolution of the Panama isthmus was influenced by numerous overlapping tectonic interactions (Farallon, Caribbean, and South America plates) since the Late Cretaceous. Tectonic reconstructions constrained by palaeomagnetic and thermochronologic data of Montes et al. (2012a, b), and zircon geochronology of Ramírez et al. (2016) suggest that significant parts of the Panamanian volcanic arc were above sea level from the middle Eocene onwards. There is also support for an emerged Panamanian landmass in Eocene time among palaeobotanical studies. Graham et al. (1985) found pollen fossil from mangroves (Rhiziphora and Pelliceria) from the Gatuncillo Formation and suggested the presence of a series of volcanic islands of moderate to low relief, with shallow seas protected by coral reefs. Fossil fruits and seeds from the middle-late Eocene Tonosí Formation also suggest presence of nearby lowland rainforests (Herrera et al. 2012). This evidence suggests that there was a landmass supporting terrestrial vegetation in close proximity to the site of deposition of Zamia nelliae. Such a landmass would have been located to the south of the present-day Panama isthmus.

As noted earlier, other putative fossils of Zamia are recorded from the Paleogene of the Caribbean Antilles. Since the early Paleogene this island chain, the proto-Antilles, may have migrated eastwards to occupy the position of the present-day Antilles (Perfit \& Williams 1989). The protoAntillean island arc may have more or less connected North and South America during the Late Cretaceous (100-70 Ma). However, it is still poorly known which areas were above sea level during the Late Cretaceous and Paleogene history of the region (Hedges 2001). Given its preservation in marine sediments, the origin of the Zamia nelliae material described here is unclear; components of the Gatuncillo fossil plant assemblage might have been transported into the sedimentary basin.

The unique taxonomic composition and high endemism of the Caribbean biota were subjected to numerous studies, though more data are available on vertebrate groups. It is estimated that about $1 / 3$ of vascular plants native to the West Indies are endemic (Adams 1972, Gentry 1992). The various biogeographic models explaining this specific diversity were established on zoological data (Perfit \& Williams 1989, Hedges 2001). The vicariance model (Rosen 1975) postulates that a Proto-Antillean biota connecting North and South America was fragmented during the Late Cretaceous by plate tectonic movement and formed the current island biotas. In contrast the dispersal model (Hedges 1996) suggests that organisms dispersed over water during the Cenozoic to reach the islands. Another theory presumes that a dry land bridge connected the Greater Antilles and South America for a short time during the mid-Cenozoic (Iturralde-Vinent \& MacPhee 1999) facilitating dispersal into the Antilles.

Concerning the origin and biogeography of Zamia some ideas have already been presented mostly in the context of fossil remains that share some characters with Zamia 
(and former Chigua). Uzunova et al. (2001) described Eostangeria ruzinciniana Uzunova, Palamarev et Kvaček, Z., the youngest species of the extinct genus Eostangeria Barthel from the middle Miocene of Bulgaria. Contrasting other members of the genus, i.e. E. saxonia Barthel (Eocene, Germany; Barthel 1976) and E. pseudopteris Kvaček, Z. et Manchester (Paleogene of North America; Kvaček, Z. \& Manchester 1999), which share general leaflet macromorphology with modern Stangeria, i.e. fern-like leaflet with a midrib and forking lateral veins departing at about 60 degrees from the midrib. Leaflets of E. ruzinciniana display a macromorphology more reminiscent to that of Zamia (Chigua) restrepoi, with lateral veins arising more steeply from the midrib. Furthermore, all members of Eostangeria share epidermal features with modern genera of subfam. Zamioideae, including Zamia. Uzunova et al. (2001) concluded that a lineage probably comprising Eostangeria and Chigua originated in North America and migrated to South America during the late Tertiary. Accordingly, this theory puts the origin of a lineage including also Zamia (Chigua) to North America (and/or Europe). Nevertheless, evidence for this theory is incomplete; fossils undoubtedly representing modern Zamia have been recorded neither from North, nor from South America, and fossils of Eostangeria have not been reported from South America. Another theory on the origin of Zamia is related to Restrepophyllum Passalia, Del Fueyo et Archangelsky described recently from the Early Cretaceous of Patagonia, Argentina (Passalia et al. 2010). Contrasting with the theory of North American origin, the authors postulate the South American origin of Zamia and its migration northwards during the Paleogene. Although in leaflet macromorphology Restrepophyllum is reminiscent of modern Zamia restrepoi (and as the authors note, also of Eostangeria ruzinciniana) its epidermal traits shows some differences from those of Zamia as well as other Zamiaceae. The strikingly uniform, epidermal, details of members of Zamioideae subfamily (the non-isodiametric, mostly elongate, somewhat irregular epidermal cells) contrast the isodiametric epidermal cells in Restrepophyllum. In this respect Restrepophyllum is more reminiscent of other extinct cycads, e.g. Ctenis, Dioonopsis. Whether the similar leaflet macromorphology of Zamia restrepoi, Eostangeria ruzinciniana, and Restrepophyllum is attributable to the phylogenetic relation of these groups remains an open question. Based on fossil floras possible migration routes during the Oligocene were suggested by Graham \& Jarzen (1969) who postulated a Caribbean land bridge through the Antilles and the Yucatan peninsula and an exchange of plant species between northern South America and the Caribbean. However, fossil evidence of Zamia supporting this model is still missing from South America.

Although the current study provides evidence that the Zamia genus appeared by the end of the Eocene or earliest Oligocene in the Central American-Caribbean region, the origin of the genus is still an unresolved issue. Moreover, the fossil from Panama may indicate an "intermediate" hypothesis in which Zamia originated in the Central American-Caribbean region and experienced subsequent south- and northward range expansion. However, it should be noted that data are presently insufficient to support any of the above ideas.

\section{Acknowledgements}

Boglárka Erdei is grateful to the Montgomery Botanical Center (MBC) for hosting this research and for giving access to its living cycad collection. The authors are indebted to Steven Manchester and Fabiany Herrera for helping with access to fossils and references, to Shusheng Hu and Peter Crane (Yale Peabody Museum), Diane Erwin (University of California), Scott Wing and Jon Wingerath (U.S. National Museum), and Andreas Kroh (Natural History Museum, Wien) for providing access to fossil specimens, and Brett Jestrow and FTBG for providing access to lab facilities. A. Hendy is appreciative to Alejandro Machado for undertaking microfossil biostratigraphy, to Carlos Jaramillo and PCP-PIRE (National Science Foundation project 0966884) for funding field work, to Ricardo Perez for donating the Toyota vehicles used for fieldwork, and the Direccion de Recursos Minerales for providing collecting permits. Funding: This work was supported by an OTKA grant (National Research, Development and Innovation Office, K 108664) and by HAESF (Hungarian-American Enterprise Scholarship Fund) supporting a long-term fellowship in MBC.

\section{References}

ADAMS, C.D. 1972. Flowering plants of Jamaica. 848 pp. University of the West Indies, Mona, Jamaica.

Archangelsky, S. 1963. A new Mesozoic flora from Ticó, Santa Cruz Province, Argentina. Bulletin of the British Museum (Natural History), Geology 8, 45-92.

Archangelsky, S. \& Petriella, B. 1971. Notas sobre la flora fósil de la zona de Ticó, Provincia de Santa Cruz. 9. Nuevos datos acerca de la morfología foliar de Mesodescolea plicata Arch. (Cycadales, Stangeriaceae). Boletín de la Sociedad Argentina de Botánica 14, 88-94.

Artabe, A. E. \& Stevenson, D. W. 1999. Fossil Cycadales of Argentina. The Botanical Review 65(3), 219-238.

DOI 10.1007/BF02857630

Barone lumaga, M.R., Coiro, M., Truernit, E., Erdei, B. \& De LuCA, P. 2015. Epidermal micromorphology in Dioon: did volcanism constrain Dioon evolution? Botanical Journal of the Linnaean Society 179(2), 236-254.

DOI 10.1111/boj.12326

Barthel, M. 1976. Eozäne Floren des Geiseltales: Farne und Cycadeen. Abhandlungen des Zentralen Geologischen Instituts, Paläontologische Abhandlungen 26, 439-498. 
BERRY, E.W. 1911. Lower Cretaceous flora of Maryland. Maryland Geological Survey, Lower Cretaceous Volume, 214-508.

Berry, E.W. 1916a. A Zamia from the lower Eocene. Torreya 16, 177-179.

Berry, E.W. 1916b. The lower Eocene floras of southeastern North America. United States Geological Survey Professional Paper 91, 1-481.

BerRY, E.W. 1917. Geologic history indicated by the fossiliferous deposits of the Wilcox group (Eocene) at Meridian, Mississippi. United States Geological Survey Professional Paper 108 E, 61-72.

Berry, E.W. 1922. Contributions to the paleobotany of Peru, Bolivia and Chile. The Johns Hopkins University Studies in Geology 4, 1-220.

Berry, E.W. 1928. Tertiary fossil plants from the Argentine Republic. Proceedings of the United States National Museum 73(22), 1-27. DOI 10.5479/si.00963801.73-2734.1

Berry, E.W. 1929. Tertiary fossil plants from Colombia, South America. Proceedings of the United States National Museum 75(24), 1-12. DOI 10.5479/si.00963801.75-2795.1

Berry, E.W. 1930. Revision of the Lower Eocene Wilcox flora of the southeastern United States. United States Geological Survey Professional Paper 156, 1-196.

Berry, E.W. 1938. Tertiary flora from the Río Pichileufú, Argentina. Geological Society of America Special Paper 12, 1-149. DOI 10.1130/SPE12-p1

Brongniart, A. 1825. Observations sur les Végétaux fossils renfermés dans les Grès de Hoer en Scanie. Annales des Sciences Naturelles 4, 200-224.

Brown, R.W. 1939. Fossil plants from the Colgate member of the Fox Hills sandstone and adjacent strata. United States Geological Survey Professional Paper 189-I, 239-275.

Brown, R.W. 1962. Paleocene flora of the Rocky Mountains and Great Plains. United States Geological Survey Professional Paper 375, 1-119.

Calonje, M., Stevenson, D.W. \& Stanberg, L. 2017. The World List of Cycads, online edition 2013-2017. http://www.cycadlist.org

Caputo, P., Cozzolino, S., De Luca, P. \& Moretti, A. 2004. Molecular phylogeny of Zamia (Zamiaceae), 149-157. In Walters, T. \& Osborne, R. (eds) Cycad classification. Concepts and recommendations. Wallingford UK CABI Publishing.

CARPenter, R.J. 1991. Macrozamia from the Early Tertiary of Tasmania and a study of the cuticles of extant species. Australian Systematic Botany 4, 433-444. DOI 10.1071/SB9910433

Chaw, S.M., Walters, T.W., Change, C.C., Hu, S.H. \& Chen, S.H. 2005. A phylogeny of cycads (Cycadales) inferred from chloroplast matK gene, trnK intron, and nuclear rDNA ITS region. Molecular Phylogenetics and Evolution 37, 214-234. DOI 10.1016/j.ympev.2005.01.006

Corro, M. \& Ротт, C. 2017. Eobowenia gen. nov. from the Early Cretaceous of Patagonia: indication for an early divergence of Bowenia? BMC Evolutionary Biology 17(97).

DOI 10.1186/s12862-017-0943-x

Cole, W.S. 1949. Upper Eocene larger Foraminifera from the Panama Canal Zone: Journal of Paleontology 23, 267-275.
CoLE, W.S. 1952. Eocene and Oligocene larger Foraminifera from the Panama Canal Zone and vicinity. United States Geological Survey Professional Paper 244, 1-41.

Condamine, F.L., Nagalingum, N.S., Marshall, C.R. \& Morlon, H. 2015. Origin and diversification of living cycads: A cautionary tale on the impact of the branching process prior in Bayesian molecular dating. BMC Evolutionary Biology 15, 65.

DOI 10.1186/s12862-015-0347-8

Coryell, H.N. \& EmBich, J.R. 1937. The Tranquilla shale (upper Eocene) of Panama and its foraminiferal fauna. Journal of Paleontology 11, 289-305.

CRANE, P.R. 1988. Major clades and relationships in the higher gymno-sperms, 218-272. In BECK, C.B. (ed.) Origin and evolution of the gymnosperms. Columbia University Press, New York.

Dumortier, B.C. 1829. Analyse des families des plantes, avec l'indication des principaux genres qui s'y rattachent. 106 pp. J. Casterman, Tournay.

Engelhardt, H. 1891. Über Tertiärpflanzen von Chile. Abhandlungen der Senckenbergischen Naturforschenden Gesellschaft 16, 629-692.

ERdei, B. \& Manchester, S.R. 2015. Ctenis clarnoensis sp. n., an unusual cycadalean foliage from the Eocene Clarno Formation, Oregon. International Journal of Plant Sciences 176(1), 31-43. DOI 10.1086/678467

Erdei, B., Akgün, F. \& Barone Lumaga, M.R. 2010. Pseudodioon akyoli nov. gen. et sp., an extinct member of Cycadales from the Turkish Miocene. Plant Systematics and Evolution 285, 33-49. DOI 10.1007/s00606-009-0253-x

Erdei, B., Manchester, S.R. \& Kvaček, Z. 2012. Dioonopsis Horiuchi et Kimura leaves from the Eocene of western North America - a cycad shared with the Paleogene of Japan. International Journal of Plant Sciences 173(1), 81-95. DOI 10.1086/662654

Florin, R. 1933. Studien über die Cycadales des Mesozoikums, nebst erörternungen über die spaltöffnungsapparate der Bennettitales. Kungliga Svenska Vetenskapsakademiens Handlingar 12, 1-134.

FontAINE, W.M. 1905. Report on various collections of fossil plants from the older Potomac of Virginia and Maryland, 476-579. In WARD, L.F. (ed.) Status of the Mesozoic floras of the United States. Second Paper. Government Printing Office Washington.

Gentry, A.H. 1992. Tropical forest biodiversity:distributional patterns and their conservational significance. Oikos 63, 19-28. DOI $10.2307 / 3545512$

Graham, A. \& JARZEN, D.M. 1969. Studies in neotropical paleobotany. I. The Oligocene communities of Puerto Rico. Annals of the Missouri Botanical Garden 56(3), 308-357. DOI 10.2307/2394849

Graham, A., Stewart, R.H. \& Stewart, J.L. 1985. Studies in Neotropical Paleobotany. III. The Tertiary Communities of Panama - Geology of the pollen-bearing deposits. Annals of the Missouri Botanical Garden 72, 485-503. DOI 10.2307/2399101

Greguss, P. 1968. Xylotomy of the living cycads with a description of their leaves and epidermis. 260 pp. Akadémiai Kiadó, Budapest. 
HARris, T.M. 1964. The Yorkshire Jurassic flora: II, Caytoniales, Cycadales \& pteridosperms. 191 pp. British Museum (Natural History), London.

Haworth, M., Fitzgerald, A. \& McElwain, J.C. 2011. Cycads show no stomatal-density and index response to elevated carbon dioxide and subambient oxygen. Australian Journal of Botany 59, 630-639. DOI 10.1071/BT11009

Hedges, S.B. 1996. Historical biogeography of West Indian vertebrates. Annual Review of Ecology and Systematics 27, 163-196. DOI 10.1146/annurev.ecolsys.27.1.163

Hedges, S.B. 2001. Biogeography of the West Indies: Overview, 15-33. In Woods, C.A. \& SergiLe, F.E. (eds) Biogeography of the West Indies. Patterns and perspectives. $2^{\text {nd }}$ edition, CRC Press, Boca Raton.

Herrera, F., Manchester, S.R. \& Jaramillo, C. 2012. Permineralized fruits from the late Eocene of Panama give clues of the composition of forests established early in the uplift of Central America. Review of Palaeobotany and Palynology 175, 10-24. DOI 10.1016/j.revpalbo.2012.02.007

Hill, K.D., Chase, M.W., Stevenson, D.W., Hills, H.G. \& Schutzman, B. 2003. The families and genera of cycads: a molecular phylogenetic analysis of Cycadophyta based on nuclear and plastid DNA sequences. International Journal of Plant Sciences 164, 933-948. DOI 10.1086/378538

HILl, R.S. 1978. Two new species of Bowenia Hook. ex Hook. f. from the Eocene of Eastern Australia. Australian Journal of Botany 26, 837-846. DOI 10.1071/BT9780837

HiLl, R.S. 1980. Three new Eocene cycads from eastern Australia. Australian Journal of Botany 28, 105-122. DOI 10.1071/BT9800105

Hollick, A. 1928. Paleobotany of Porto Rico. New York Academy, Scientific Survey of Porto Rico and the Virgin Islands 7(3), 177-393.

Hollick, A. 1932. Description of new species of Tertiary cycads, with a review to those previously recorded. Bulletin of the Torrey Botanical Club 59, 169-189. DOI 10.2307/2480541

Horaninow, P. 1934. Primae Lineae Systematis Naturae, nexui naturali omnium evolutionique progressivae per nixus reascendentes superstructi. 142 pp. Karoli Krajanis, St. Petersburg.

Horiuchi, J. \& Kimura, T. 1987. Dioonopsis gen. et sp. nov., a new cycad from the Palaeogene of Japan. Review of Palaeobotany and Palynology 51, 213-225. DOI 10.1016/0034-6667(87)90031-5

Iturralde-Vinent, M.A. \& MacPhee, R.D.E. 1999. Paleogeography of the Caribbean region: implications for Cenozoic biogeography. Bulletin of the American Museum of Natural History 238, 1-95.

Jones, T.P. \& Rowe, N.P. (eds) 1999. Fossil plants and spores: modern techniques. 396 pp. Geological Society of London, London \& Bath.

Knowlton, F.H. 1930. The flora of the Denver and associated formations of Colorado. United States Geological Survey Professional Paper 155, 1-142.

KrasSER, F. 1903. Konstantin von Ettingshausen's Studien über die fossile Flora von Ouriçanga in Brasilien. Sitzungsbericht der Akademie der Wissenschaften zu Wien 112, 852-860.

Kustatscher, E. \& VAn Konijnenburg-Van Cittert, J.H.A. 2010. Seed ferns and Cycadophytes from the Triassic Flora of Thale (Germany). Neues Jahrbuch für Geologie und Paläontologie Abhandlungen 258, 195-217.

DOI 10.1127/0077-7749/2010/0097

KVAČEK, J. 1995. Cycadales and Bennettitales leaf compressions of the Bohemian Cenomanian, Central Europe. Review of Palaeobotany and Palynology 84(3/4), 389-412. DOI 10.1016/0034-6667(94)00093-Y

KVAČEK, J. 1999. New data and revision of three gymnosperms from the Cenomanian of Bohemia - Sagenopteris variabilis (Velenovsky) Velenovsky, Mesenea bohemica (Corda) comb. n. and Eretmophyllum obtusum (Velenovsky) comb. n. Acta Musei Nationalis Pragae series B - Historia Naturalis 55(1/2), 15-27.

KVAČEK, Z. 2002. A new Tertiary Ceratozamia (Zamiaceae, Cycadopsida) from the European Oligocene. Flora 197, 303-316. DOI 10.1078/0367-2530-00044

KVAČEK, Z. 2004. A noteworthy cycad, Ceratozamia hofmannii Ettingshausen 1887, from the Lower Miocene of Austria reexamined. Neues Jahrbuch für Geologie und Paläontologie Monatshefte 2, 111-118.

KVAČEK, Z. 2014. New fossil records of Ceratozamia (Zamiaceae, Cycadales) from the European Oligocene and lower Miocene. Acta Palaeobotanica 54(2), 231-247.

DOI 10.2478/acpa-2014-0012

KVAČEK, Z. \& MANCHESTER, S.R. 1999. Eostangeria Barthel (extinct Cycadales) from the Palaeogene of western North America and Europe. International Journal of Plant Sciences 160, 621-629. DOI $10.1086 / 314152$

LinnAeus, C. 1763. Species Plantarum, exhibentes plantas rite cognitas, ad genera relatas, cum difrerentiis specifis, nomnibus trivialibus, synonymis selectis, locis natalibus, secundus systema sexuale digestas. 1684 pp. Impensis direct. Lauretii Salvii, Stockholm.

Lindley, J. \& Hutton, W. 1834. The fossil flora of Great Britain. Vol 2. 208 pp. Ridgway, London.

Manchester, S.R. 2014. Revisions to Roland Brown's North American Paleocene flora. Acta Musei Nationalis Pragae series B - Historia Naturalis 70(3/4), 153-210.

DOI 10.14446/AMNP.2014.153

MenÉndez, C.A. 1965. Sueria rectinervis n. gen. et sp. de la flora fósil de Ticó, Provincia de Santa Cruz. Ameghiniana 4, 3-11.

Montes, C., Cardona, A., McFadden, R.R., Moron, S.E., Silva, C.A., Restrepo-Moreno, S.A., Ramirez, D.A., Hoyos, N., Wilson, J., Farris, D., Bayona, G.A., Jaramillo, C.A., Valencia, V., Bryan, J. \& Flores, J.A. 2012a. Evidence for middle Eocene and younger land emergence in Central Panama: implications for Isthmus closure. Bulletin of the Geological Society of America 39, 1-20. DOI 10.1130/B30528.1

Montes, C., Bayona, G., Cardona, A., Silva, C., Morón, S., Hoyos, N., Ramírez, D., Jaramillo, C.A. \& Valencia, V. 2012b. ArcContinent Collision and Orocline Formation: Closing of the 
Central American seaway. Journal of Geophysical Research, Solid Earth 117, B04105. DOI 10.1029/2011JB008959

Nagalingum, N.S., Marshall, C.R., Quental, T.B., Rai, H.S., LittLe, D.F. \& Mathews, S. 2011. Recent synchronous radiation of a living fossil. Science 334, 796-799.

Norstog, K.J. \& Nicholls, T.J. 1997. The biology of the cycads. 504 pp. Cornell University Press, Ithaca.

DOI 10.1126/science.1209926

Palamarev, E. \& Uzunova, K. 1992. Beiträge zur Entwicklung der Cycadeen in der Tertiärflora Europas. Courier Forschungsinstitut Senckenberg 147, 287-293.

Passalia, M.G., Del Fueyo, G. \& Archangelsky, S. 2010. An Early Cretaceous zamiaceous cycad of south west Gondwana: Restrepophyllum nov. gen. from Patagonia, Argentina. Review of Palaeobotany and Palynology 161(3), 137-150.

DOI 10.1016/j.revpalbo.2010.04.001

Perfit, M.R. \& Williams, E.E. 1989. Geological constraints and biological retrodictions in the evolution of the Caribbean Sea and its islands, 47-102. In Woods, C.A. (ed.) Biogeography of the West Indies: past, present, and future. Sandhill Crane Press, Gainesville, Florida.

Potвury, S. 1935. The La Porte flora of Plumas County, California. Carnegie Institution of Washington Publication 465, $29-82$.

Pott, C., Kerp, H. \& Krings, M. 2007a. Morphology and epidermal anatomy of Nilssonia (cycadalean foliage) from the Upper Triassic of Lunz (Lower Austria). Review of Palaeobotany and Palynology 143(3), 197-217.

DOI 10.1016/j.revpalbo.2006.07.007

Pott, C., Kerp, H. \& Krings, M. 2007b. Pseudoctenis cornelii nov. spec.(cycadalean foliage) from the Carnian (Upper Triassic) of Lunz, Lower Austria. Annalen des Naturhistorischen Museums. Wien 109 A, 1-17.

Pott, C., McLoughlin, S., Lindström, A., Shunging, W. \& Fris, E.M. 2012. Baikalophyllum lobatum and Rehezamites anisolobus: two seed plants with "cycadophyte" foliage from the Early Cretaceous of eastern Asia. International Journal of Plant Sciences 173(2), 192-208. DOI 10.1086/663276

Ramírez, D.A., Foster, D.A., Min, K., Montes, C., Cardona, A. \& SAdove, G. 2016. Exhumation of the Panama basement complex and basins: Implications for the closure of the Central American seaway. Geochemistry, Geophysics, Geosystems 17, 1-20. DOI 10.1002/2016GC006289

RoSEN, D.E. 1975. A vicariance model of Caribbean biogeography. Systematic Biology 24(4), 431-464.

DOI 10.1093/sysbio/ 24.4.431

Salas-Leiva, D.E., Meerow, A.W., Calonje, M., Griffith, M.P., Francisco-Ortega, J., Nakamura, K., Stevenson, D.W., Lewis, C.E. \& NamofF, S. 2013. Phylogeny of the cycads based on multiple single-copy nuclear genes: congruence of concatenated parsimony, likelihood and species tree inference methods. Annals of Botany 112(7), 1263-1278. DOI 10.1093/aob/mct192
Schutzman, B.M. 1998. Revisionary studies of Mesoamerican Zamia L. (Zamiaceae, Cycadales). 543 pp. Ph.D. thesis, University of Florida, Gainesville, Florida, USA.

SEwARD, A.C. 1911. The Jurassic flora of Sutherland. Transactions of the Royal Society of Edinburgh 47, 643-709. DOI 10.1017/S0080456800003872

Stevenson, D.W. 1990. Morphology and systematics of the Cycadales. Memoirs of the New York Botanical Garden 57, 8-55.

Su, K., Quan, C. \& Liu, Y.S.C. 2014. Cycas fushunensis sp. nov. (Cycadaceae) from the Eocene of northeast China. Review of Palaeobotany and Palynology 204, 43-49.

DOI 10.1016/j.revpalbo.2014.02.008

Tripati, A. \& ZAChos, J. 2002. Late Eocene tropical sea surface temperatures: A perspective from Panama. Paleoceanography 17(3), 4/1-4/14.

Uzunova, K., Palamarev, E. \& Kvaček, Z. 2001. Eostangeria ruzinciniana (Zamiaceae) from the Middle Miocene of Bulgaria and its relationship to similar taxa of fossil Eostangeria, and extant Chigua and Stangeria (Cycadales). Acta Palaeobotanica 41, 177-193.

Villar de Seoane, L. 2005. New cycadalean leaves from the Anfiteatro de Ticó Formation, Early Aptian, Patagonia, Argentina. Cretaceous Research 26(4), 540-550.

DOI 10.1016/j.cretres.2005.02.004

WARD, L.F. 1895. The Potomac Formation. Fifteenth Annual Report of the United States Geological Survey 1893-1894, 313-397.

WARD, L.F. 1905. Status of the Mesozoic floras of the United States. United States Geological Survey 48, 1-616.

Watson, J. \& Cusack, H.A. 2005. Cycadales of the English Wealden. Monograph of the Palaeontographical Society 158 , $1-189$.

WATT, A.D. 1971. Validation of names of species of fossil plants described by RW Brown in 1962. Taxon 20(4), 639-640. DOI 10.2307/1218282

Wilf, P., Escapa, I.H., Cúneo, N.R., Kooyman, R.M., Johnson, K.R. \& Iglesias, A. 2014. First South American Agathis (Araucariaceae), Eocene of Patagonia. American Journal of Botany 101(1), 156-179. DOI 10.3732/ajb.1300327

Wilf, P., Stevenson, D.W. \& Cúneo, N.R. 2016. The last Patagonian cycad, Austrozamia stockeyi gen. et sp. nov., early Eocene of Laguna del Hunco, Chubut, Argentina 1. Botany 94(9), 817 -829. DOI 10.1139/cjb-2016-0038

Woodring, W.P. 1973. Geology and paleontology of Canal zone and adjoining parts of Panama. Geological Survey Professional Paper 306E, 453-539.

Yokoyama, M. 1911. Some Tertiary fossils from the Miike CoalField. Journal of the College of Science Imperial University of Tokyo 27(20), 1-16.

Zijlstra, G., Kustatscher, E. \& Van KonijnenburG-Van Cittert, J.H.A. 2009. Proposal to conserve the name Sphenozamites (fossil Cycadophyta). Taxon 58(3), 1016. 